\title{
Problem-based learning in medical degree teaching: a scoping review
}

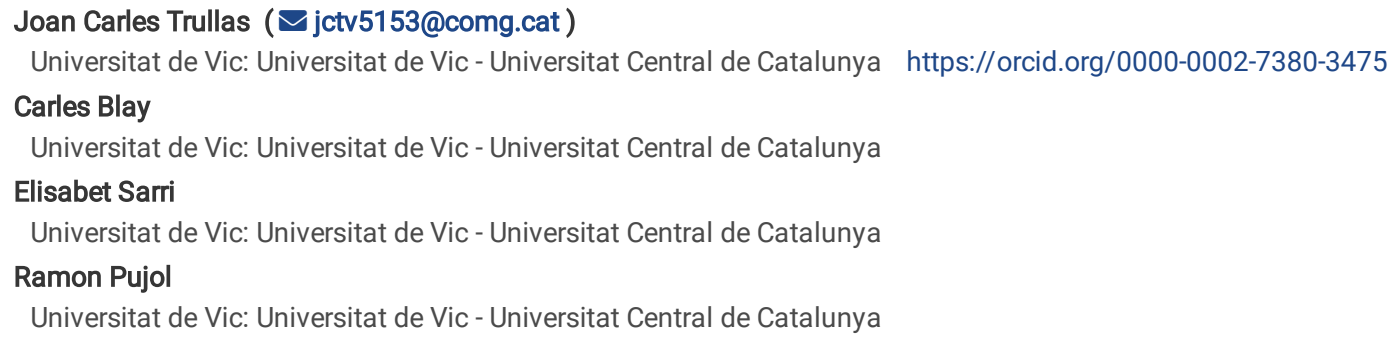

\section{Research Article}

Keywords: education, learning, medicine, problem-based learning, systematic review, teaching

Posted Date: May 17th, 2021

DOI: https://doi.org/10.21203/rs.3.rs-514038/v1

License: @ (i) This work is licensed under a Creative Commons Attribution 4.0 International License. Read Full License 


\section{Abstract}

Problem-based learning (PBL) is a pedagogical approach that shifts the role of the teacher to the student (student-centred) and is based on self-directed learning. Although PBL has been adopted in undergraduate and postgraduate medical education, the effectiveness of the method is still under discussion. We employed a scoping review to appraise available international evidence concerning to the effectiveness and usefulness of PBL methodology in undergraduate medical teaching programs. We applied the Arksey and O'Malley framework to undertake a scoping review. A search of literature published in English and Spanish identified one hundred and twenty four publications eligible for this review. Despite the fact that this review includes many studies, their design is heterogeneous and only a few provide a high scientific evidence methodology (randomized design and/or systematic review with meta-analysis). Furthermore, most are single-center experiences with small sample size and there are no large multi-center studies. PBL methodology obtains a high level of satisfaction, especially among students. It is more effective than other more traditional (or lecture-based methods) at improving social and communication skills, problemsolving and self-learning skills. Knowledge retention and academic performance are no worse (and in many studies are better) than with traditional methods. $\mathrm{PBL}$ is not universally widespread, probably because it requires greater human resources and continuous training for its implementation. More comparative and randomized studies and/or other systematic reviews and meta-analysis are required to determine which educational strategies are the most suitable for training the doctors of the future.

\section{Background}

There has always been enormous interest in identifying the best learning methods. In the mid-twentieth century, US educator Edgar Dale proposed which actions would lead to deeper learning than others and published the well-known (and at the same time controversial) "Cone of Experience or Cone of Dale". At the apex of the cone are oral representations (verbal descriptions, written descriptions, etc.) and at the base is direct experience (based on a person carrying out the activity that they aim to learn), which represents the greatest depth of our learning. In other words, each level of the cone corresponds to various learning methods. At the base are the most effective, participative methods (what we do and what we say) and at the apex are the least effective, abstract methods (what we read and what we hear) (Dale 1932). In 1990, psychologist George Miller proposed a framework pyramid to assess clinical competence. At the lowest level of the pyramid is knowledge (knows), followed by the competence (knows how), execution (shows how) and finally the action (does) (Miller 1990). Both Miller's pyramid and Dale's cone propose a very efficient way of training and, at the same time, of evaluation. Miller suggested that the learning curve passes through various levels, from the acquisition of theoretical knowledge to knowing how to put this knowledge into practice and demonstrate it. Dale stated that to remember a high percentage of the acquired knowledge, a theatrical representation should be carried out or real experiences should be simulated.

In the last 50 years, various university education models have emerged and have attempted to reconcile teaching with learning, according to the principle that students should lead their own learning process. Perhaps one of the most successful models is problem-based learning (PBL) that came out of the Englishspeaking environment. There are many descriptions of PBL in the literature, but in practice there is great variability in what people understand by this methodology. The original conception of PBL as an educational strategy in medicine was initiated at McMaster University (Canada) in 1969, leaving aside the traditional methodology (which is often based on lectures) and introducing student-centred learning. The new formulation of medical education proposed by McMaster did not separate the basic sciences from the clinical sciences, and partially abandoned theoretical classes, which were taught after the presentation of the problem. In its original version, $\mathrm{PBL}$ is a methodology in which the starting point is a problem or a problematic situation. The situation enables students to develop a hypothesis and identify learning needs so that they can better understand the problem and meet the established learning objectives (Branda 2013; Bodagh N et al. 2017).

As attractive as the PBL method may seem, we should consider whether it is really useful and effective as a learning method. Although PBL has been adopted in undergraduate and postgraduate medical education, the effectiveness of the method is still under discussion. This is due partly to the methodological difficulty in comparing PBL with traditional curricula based on lectures.

The primary goal of this study was to appraise available international evidence concerning to the effectiveness and usefulness of PBL methodology in undergraduate medical teaching programs. As the intention was to synthesize the scattered evidence available, the option was to conduct a scoping review. A scoping study tends to address broader topics where many different study designs might be applicable. Scoping studies may be particularly relevant to disciplines, such as medical education, in which the paucity of randomized controlled trials makes it difficult for researchers to undertake systematic reviews (Arksey and O'Malley 2005; Levac et al. 2010). Even though the scoping review methodology is not widely used in medical education, it is well established for synthesizing heterogeneous research evidence (Pham et al. 2014).

The specific aims were: 1) to determine the effectiveness of PBL in learning and retention of knowledge in medical education; 2 ) to determine the effectiveness of PBL for social and communication skills in medical education; 3 ) know the level of satisfaction perceived by the medical students (and/or tutors) when they are taught with the PBL methodology (or when they teach in case of tutors).

\section{Methods}

This review was guided by Arksey and O'Malley's methodological framework for conducting scoping reviews. The five main stages of the framework are: (1) identifying the research question; (2) ascertaining relevant studies; (3) determining study selection; (4) charting the data; and (5) collating, summarising and reporting the results (Arksey and O'Malley 2005). We reported our process according to the PRISMA Extension for Scoping Reviews (Tricco et al. 2018).

\section{Stage 1: Identifying the research question}


With the goals of the study established, the four members of the research team established the research questions. The primary research question was "Which is the effectiveness of PBL methodology for teaching in undergraduate medicine?" The secondary questions include "Which is the perception and satisfaction of medical students and tutors in relation to PBL methodology?"

\section{Stage 2: Identifying relevant studies}

After the research questions and a search strategy were defined, the searches were conducted in PubMed and Web of Science using the MeSH terms "problembased learning" and "Medicine" (the Boolean operator "AND" was applied to the search terms). No limits were set on language, publication date, study design or country of origin. The search was carried out on 14th February 2021. Citations were uploaded to the reference manager software Mendeley Desktop (version 1.19.8) for title and abstract screening, and data characterization.

Stage 3: Study selection

The searching strategy in our scoping study generated a total of 2399 references. The literature search and screening of title, abstract and full-text for suitability was performed independently by one author (JCT) based on predetermined inclusion criteria. The inclusion criteria were: 1) PBL methodology was the major research topic; 2) participants were undergraduate medical students or tutors; 3 ) the main outcomes were one of the following: knowledge retention, social and communication skills and/or student/tutor satisfaction; 4) all types of studies were included including descriptive papers, qualitative, quantitative and mixed studies methods, perspectives, opinion, commentary pieces and editorials. Exclusion criteria were studies including other types of participants such as postgraduate medical students, residents and other health non-medical specialties such as pharmacy, veterinary, dentistry or nursing. Studies published in languages other than Spanish and English were also excluded. Situations in which uncertainty arose, all authors (CB, BS, RP) discussed the publication together to reach a final consensus. The outcomes of the search results and screening are presented in Fig. 1. One-hundred and twenty-four articles met the inclusion criteria and were included in the final analysis.

\section{Stage 4: Charting the data}

A data extraction table was developed by the research team. Data extracted from each of the 124 publications included general publication details (year, author, and country), sample size, study population, design/methodology, main and secondary outcomes and relevant results and/or conclusions. We compiled all data into a single spreadsheet in Microsoft Excel for coding and analysis. The characteristics and the study subject of the 124 articles included in this review are summarized in Tables 1, 2 and 3. The detailed results of the Microsoft Excel file are also shown in Table 4.

\section{Results}

\section{Stage 5: Collating, summarizing and reporting the results}

As indicated in the search strategy (Fig. 1) this review resulted in the inclusion of 124 publications. Publication years of the final sample ranged from 1990 to 2020 and the distribution of publications by years is shown in Fig. 2. The majority of the publications (51, 41\%) were identified for the years $2010-2020$ and the years in which there were more publications were 2001, 2009 and 2015. Countries from the six continents were represented in this review. Most of the publications were from Asia (especially China and Saudi Arabia) and North America followed by Europe, and few studies were from Africa, Oceania and South America. The country with more publications was the United States of America $(n=27)$. The most frequent designs of the selected studies were surveys or questionnaires ( $n=45)$ and comparative studies ( $n=48$, only 16 were randomized) with traditional or lecture-based learning methodologies (in two studies the comparison was with simulation) and the main outcome was performance followed by student satisfaction (45 studies measured more than one outcome). The studies with the highest level of scientific evidence (systematic review and meta-analysis and randomized studies) were conducted mostly in Asian countries (Tables 1 and 3). The study subject was specified in 81 publications finding a high variability but at the same time great representability of almost all disciplines of the medical studies (Table 2).

The sample size was available in 99 publications and the median [range] of the participants was 132 [14-2061]. According to study population, there were more participants in the students' focused studies (median 134 and range 16-2061) in comparison with the tutors' studies (median 53 and range 14-494)

Finally, after reviewing in detail the measured outcomes (main and secondary) according to the study design (Tables 3 and 4 ) we present a narrative overview and a synthesis of the main findings.

\section{Leaming and knowledge retention}

Seventy-five of the 124 publications had learning and/or knowledge retention as their main or secondary outcomes, most of them (45) were comparative studies with traditional or lecture-based learning and 16 were randomized. These studies were varied in their methodology, were performed in different geographic zones, and normally analysed the experience of just one education centre. Most studies (53) reported superiority of PBL in learning and knowledge acquisition (Sokas et al. 1990; Richards et al. 1996; Gresham \& Philp 1996; Hill et al. 1998; Blake \& Parkison 1998; Hmelo 1998; Finch 1999; Casassus et al. 1999; Purdy et al. 1999; Farrell et al. 1999; Finch 1999; Curtis et al. 2001; Trevena \& Clarke 2002; Astin et al. 2002; Whitfield et al. 2002; Whitfield et al. 2002; McParland et al. 2004; Casey et al. 2005; Gurpinar et al. 2005; Tamblyn et al. 2005; Abu-Hijleh et al. 2005; Distlehorst et al. 2005; Distlehorst et al. 2005; Hoffman et al. 2006; Kong et al. 2009; Tsou et al. 2009; Tsou et al. 2009; Wang et al. 2010; Abou-Elhamd et al. 2011; Urrutia et al. 2101; Tian et al. 2012; Hoover et al. 2012; Li et al. 2013; Ding et al. 2014; Meo 2014; Khoshnevisasl et al. 2014; Al-Drees et al. 2015; Al-Shaikh et al. 2015; Hande et al. 2015; González et al. 2015; Yanamadala et al. 2016; Balendran \& John 2017; Chang et al. 2017; Eltony et al. 2017; Zhang et al. 2018; Hincapié et al. 2018; Ma \& Lu 2019; Berger et al. 2019; Alquliti et al. 2019; Li et al. 2020; Zhao et al. 2020; Liu et al. 2020; Margolius et al. 2020) but there was no difference between traditional and PBL curriculums in another 19 studies (Schwart et al. 1992; Mennin et al. 1993; Vernon, \& Hosokawa 1996; Kaufman \& Mann 1998; Kaufman \& Mann 1999; Antepohl \& Herzig 1999; Dyke et al. 2001; Brewer 2001; Seneviratne et al. 2001; Alleyne et al. 2002; Norman et al. 2008; Cohen-Schotanus et al. 2008; Wenk et al 2009; Collard et al. 2009; Nouns et al. 2012; Saloojee \& van Wyk et al. 2012; Mughal \& Shaikh et al. 2018; Hu et al. 2019; Thompson et al. 2019). Only three studies reported that PBL was less effective (Vernon \& Hosokawa 1996; Steadman et al. 2006; Johnston et al. 2009), in one case favouring simulation-based 
learning (Steadman et al. 2006). It is noteworthy that the four systematic reviews and meta-analysis included in this scoping review, all carried out in China, found that PBL was more effective than lecture-based learning in improving knowledge and other skills (clinical, problem-solving, self-learning and collaborative) (Ding et al. 2014; Zhang et al. 2018; Ma et al. 2019; Liu et al. 2020). Another relevant example of the superiority of the PBL method over the traditional method is the experience reported by (Hoffman et al. 2006) from the University of Missouri-Columbia. The authors analysed the impact of implementing the PBL methodology in its Faculty of Medicine and revealed an improvement in the academic results that lasted for over a decade.

\section{Social and communication skills}

We found five studies in this scoping review that focussed on these outcomes and all of them described that a curriculum centred on PBL seems to instil more confidence in social and communication skills among students. Students perceived PBL positively for team work, communication skills and interpersonal relations (Seneviratne et al. 2001; Suleman et al. 2010; Hande et al. 2015; Al-Shaikh et al. 2015; Mughal \& Shaikh 2018).

\section{Student satisfaction}

Fifty-six publications analysed student satisfaction with PBL methodology. The most frequent methodology were surveys or questionnaires (29 studies) followed by comparative studies with traditional or lecture-based methodology ( 19 studies, 7 of them were randomized). Almost all the studies (47) have shown that PBL is generally well-received (Sokas et al. 1990; Blosser \& Jones 1991; Usherwood 1991; Bernstein et al. 1995; Kaufman \& Mann 1996; Kalaian \& Mullan 1996; Gresham \& Philp 1996; Vincelette 1997; Kaufman \& Mann 1999; Antepohl \& Herzig 1999; Casassus et al. 1999; Purdy et al. 1999; Farrell et al. 1999; Ghosh \& Dawka 2000; Dyke et al. 2001; Walters 2001; Leung et al 2001; Khoo et al. 2001; Villamor 2001; Curtis et al. 2001; Trevena \& Clarke 2002; Chang et al. 2004; McLean 2004; Casey et al. 2005; Abu-Hijleh et al. 2005; Lucas et al. 2006; Burgun et al. 2006; Gurpinar et al. 2009; Suleman et al. 2010; Wang et al. 2010; Tian et al. 2012; Elzubeir 2012; Sulaiman \& Hamdy 2013; Albarrak et al. 2013; Li et al. 2013; Meo 2014; Khoshnevisasl et al. 2014; Nosair et al. 2015; González et al. 2015; Tshitenge et al. 2017; Eltony et al. 2017; Yadav et al. 2018; Asad et al. 2019; Mpalanyi et al. 2020; Korkmaz \& Ozcelik 2020; Li et al. 2020; Liu et al. 2020) but in 9 studies the overall satisfaction scores for the PBL program were neutral (Macallan et al. 2009; Grisham et al. 2015; Khan \& Al-Swailmi 2015; Alduraywish et al. 2017; Yoo et al. 2019; Aldayel et al. 2019; Hu et al. 2019) or negative (DeLowerntal 1996; Tufts 2009). Some factors that have been identified as key components for PBL to be successful include: a small group size, the use of scenarios of realistic cases and good management of group dynamics. Despite a mostly positive assessment of the PBL methodology by the students, there were some negative aspects that could be criticized or improved. These include unclear communication of the learning methodology, objectives and assessment method; bad management and organisation of the sessions; tutors having little experience of the method; and a lack of standardisation in the implementation of the method by the tutors.

Tutor satisfaction

There are only 12 publications that analyze the satisfaction of tutors, most of them surveys or questionnaires (Bernstein et al. 1995; Vincelette et al. 1997; Khoo et al. 2001; Gurpinar et al. 2009). In comparison with the satisfaction of the students, here the results are more neutral (Macallan et al. 2009; Subramaniam et al. 2014; Khan \& Al-Swailmi 2015; Chang 2016; Yoo et al 2019) and even unfavorable to the PBL methodology in two publications (Griffith et al 1996; De Lowerntal 1996). PBL teaching was favored by tutors when the institutions train them in the subject, when there was administrative support and adequate infrastructure and coordination (Navarro \& Zamora 2014). In some experiences, the PBL modules created an unacceptable toll of anxiety, unhappiness and strained relations.

\section{Other outcomes and descriptive experiences}

The effectiveness of the PBL methodology has also been explored in other outcomes such as the ability to solve problems and to self-directed learning. All studies have shown that PBL is more effective than lecture-based learning in problem-solving and self-learning skills (Casassus et al. 1999; Seneviratne et al. 2001; Whitfield et al. 2002; Ding et al. 2014; Balendran \& John 2017; Mughal \& Shaikh 2018; Yadav et al. 2018; Villamor 2001; Demiroren et al. 2016).

Finally, other publications have reported the experience of some faculties in the implementation of the PBL methodology. Different experiences have demonstrated that it is both possible and feasible to shift from a traditional curriculum to a PBL program, recognizing that PBL methodology is complex to plan and structure, needs a large number of human and material resources, requiring an immense teacher effort (Desmarchais 2003; Chang et al. 2004; Tamblyn et al. 2005; Hoffman et al. 2006). In addition, and in spite of its cost implication, a PBL curriculum can be successfully implemented in resourceconstrained settings (Amoako-Sakyi \& Amonoo-Kuofi 2015; Carrera et al. 2003).

\section{Discussion}

We conducted this scoping review to explore the effectiveness and satisfaction of PBL methodology for teaching in undergraduate medicine and, to our knowledge, it is the first study of its kind that has been carried out. PBL methodology is implemented in medical studies on the 6 continents but there is more experience (or at least more publications) from Asian countries and North America. In spite of its difficulties on implementation, a PBL curriculum can be successfully implemented in resource-constrained settings (Amoako-Sakyi \& Amonoo-Kuofi 2015; Carrera et al. 2003). Although it is true that the studies with the highest level of scientific evidence (randomized studies and meta-analysis) were carried out mainly in Asian countries (and some in North America and Europe), there were no significant differences in the main results according to geographical origin.

In this scoping review we have included a large number of publications that, despite their heterogeneity, tend to show favorable results for the usefulness of the PBL methodology in teaching and learning medicine. The results tend to be especially favorable to PBL methodology when it is compared with traditional or lecture-based teaching methods, but when compared with simulation it is not so clear. There are two studies that show neutral (Wenk et al. 2009) or superior (Steadman et al. 2006) results to simulation for the acquisition of specific clinical skills. It seems important to highlight that the four meta-analysis included in this review, which included a high number of participants, show results that are clearly favorable to the PBL methodology in terms of knowledge, clinical skills, problem-solving, self-learning and satisfaction (Ding et al. 2014; Zhang et al. 2018; Ma et al. 2019; Liu et al. 2020). 
Regarding the level of satisfaction described in the surveys or questionnaires, the overall satisfaction rate was higher in the PBL students when compared with traditional learning students. Students work in small groups, allowing and promoting teamwork and facilitating social and communication skills. As sessions are more attractive and dynamic than traditional classes, this could lead to a greater degree of motivation for learning.

These satisfaction results are not so favorable when tutors are asked and this may be due to different reasons; first, some studies are from the 90 s, when the methodology was not yet fully implemented; second, the number of tutors included in these studies is low; and third, and perhaps most importantly, the complaints are not usually due to the methodology itself, but rather due to lack of administrative support, and/or work overload. PBL methodology implies more human and material resources. The lack of experience in guided self-learning by lecturers requires more training. Some teachers may not feel comfortable with the method and therefore do not apply it correctly.

Despite how effective and/or attractive the PBL methodology may seem, some (not many) authors are clearly detractors and have published opinion articles with fierce criticism to this methodology. Some of the arguments against are as follows: clinical problem solving is the wrong task for preclinical medical students, self-directed learning interpreted as self-teaching is not appropriate in undergraduate medical education, relegation to the role of facilitators is a misuse of the faculty, small-group experience is inherently variable and sometimes dysfunctional, etc. (Shanley 2007).

\section{Limitations}

Scoping reviews are not without limitations. Our review includes 124 articles from the 2399 initially identified and despite our efforts to be as comprehensive as possible, we may have missed some articles. Despite the fact that this review includes many studies, their design is very heterogeneous, only a few include a large sample size and high scientific evidence methodology. Furthermore, most are single-center experiences and there are no large multi-center studies. However, the adoption of a scoping review methodology was effective in terms of summarizing the research findings, identifying limitations in studies' methodologies and findings and provided a more rigorous vision of the international stat of the art.

\section{Conclusions}

This systematic scoping review provides a broad overview of the efficacy of PBL methodology in undergraduate medicine teaching from different countries and institutions. PBL is not a new teaching method given that it has already been 50 years since it was implemented in medicine courses. It is a method that shifts the leading role from teachers to students and is based on guided self-learning. If it is applied properly, the degree of satisfaction is high, especially for students. PBL is more effective than traditional methods (based mainly on lectures) at improving social and communication skills, problem-solving and selflearning skills, and has no worse results (and in many studies better results) in relation to knowledge retention and academic performance. Despite that, its use is not universally widespread, probably because it requires greater human resources and continuous training for its implementation. In any case, more comparative and randomized studies and/or other systematic reviews and meta-analysis are required to determine which educational strategies could be most suitable for the training of future doctors.

\section{Declarations}

\section{Compliance with ethical standards}

Funding: no funding was received for conducting this study

Conflict of interest: all authors declare that they have no conflict of interest.

Ethical approval: not applicable for a literature review

Author Contribution statement: JCT: had the idea for the article; JCT performed the literature search and data analysis; JCT drafted the first version of the manuscript. CB, BS and RP contributed to the data analysis and suggested revisions to the manuscript. All authors read and approved the final manuscript.

\section{References}

Aboonq, M. (2015). Perception of the faculty regarding problem-based learning as an educational approach in Northwestern Saudi Arabia. SAUDI MEDICAL JOURNAL, 36(11), 1329-1335. https://doi.org/10.15537/smj.2015.11.12263

Aboonq, M., Alquliti, A., Abdulmonem, I., Alpuq, N., Jalali, K., \& Arabi, S. (2019). STUDENTS' APPROACHES TO LEARNING AND PERCEPTION OF LEARNING ENVIRONMENT: A COMPARISON BETWEEN TRADITIONAL AND PROBLEM-BASED LEARNING MEDICAL CURRICULA. INDO AMERICAN JOURNAL OF PHARMACEUTICAL SCIENCES, 6(2), 3610-3619. https://doi.org/10.5281/zenodo. 2562660

Abou-Elhamd, K. A., Rashad, U. M., \& Al-Sultan, A. I. (2011). Applying problem-based learning to otolaryngology teaching. The Journal of Laryngology and Otology, 125(2), 117-120. https://doi.org/10.1017/S0022215110001702

Abu-Hijleh, M. F., Chakravarty, M., Al-Shboul, Q., Kassab, S., \& Hamdy, H. (2005). Integrating applied anatomy in surgical clerkship in a problem-based learning curriculum. Surgical and Radiologic Anatomy: SRA, 27(2), 152-157. https://doi.org/10.1007/s00276-004-0293-4

Albarrak, A. I., Mohammed, R., Abalhassan, M. F., \& Almutairi, N. K. (2013). Academic satisfaction among traditional and problem based learning medical students A comparative study. SAUDI MEDICAL JOURNAL, 34(11), 1179-1188. 
Aldayel, A. A., Alali, A. O., Altuwaim, A. A., Alhussain, H. A., Aljasser, K. A., Bin Abdulrahman, K. A., Alamri, M. O., \& Almutairi, T. A. (2019). Problem-based learning: medical students' perception toward their educational environment at Al-Imam Mohammad Ibn Saud Islamic University. ADVANCES IN MEDICAL EDUCATION AND PRACTICE, 10, 95-104. https://doi.org/10.2147/AMEP.S189062

Al-Drees, A. A., Khalil, M. S., Irshad, M., \& Abdulghani, H. M. (2015). Students' perception towards the problem based learning tutorial session in a system-based hybrid curriculum. SAUDI MEDICAL JOURNAL, 36(3), 341-348. https://doi.org/10.15537/smj.2015.3.10216

Alduraywish, A. A., Mohager, M. O., Alenezi, M. J., Nail, A. M., \& Aljafari, A. S. (2017). Evaluation of students' experience with Problem-based Learning (PBL) applied at the College of Medicine, Al-Jouf University, Saudi Arabia. JOURNAL OF THE PAKISTAN MEDICAL ASSOCIATION, 67(12), 1870-1873.

Alleyne, T., Shirley, A., Bennett, C., Addae, J., Walrond, E., West, S., \& Pinto Pereira, L. (2002). Problem-based compared with traditional methods at the Faculty of Medical Sciences, University of the West Indies: a model study. Medical Teacher, 24(3), 273-279. https://doi.org/10.1080/01421590220125286

Al-Shaikh, G., Al Mussaed, E. M., Altamimi, T. N., Elmorshedy, H., Syed, S., \& Habib, F. (2015). Perception of Medical Students Regarding Problem Based Learning. KUWAIT MEDICAL JOURNAL, 47(2), 133-138.

Amoako-Sakyi, D., \& Amonoo-Kuofi, H. (2015). Problem-based learning in resource-poor settings: lessons from a medical school in Ghana. BMC MEDICAL EDUCATION, 15. https://doi.org/10.1186/s12909-015-0501-4

Antepohl, W., \& Herzig, S. (1999). Problem-based learning versus lecture-based learning in a course of basic pharmacology: a controlled, randomized study. MEDICAL EDUCATION, 33(2), 106-113. https://doi.org/10.1046/j.1365-2923.1999.00289.x

Arksey H \& O’Malley L. (2005). Scoping studies: towards a methodological framework. International Journal of Social Research Methodology, 8(1), 19-32. doi:10.1080/1364557032000119616

Asad, M. R., Tadvi, N., Amir, K. M., Afzal, K., Irfan, A., \& Hussain, S. A. (2019). Medical Student's Feedback towards Problem Based Learning and Interactive Lectures as a Teaching and Learning Method in an Outcome-Based Curriculum. INTERNATIONAL JOURNAL OF MEDICAL RESEARCH I\& HEALTH SCIENCES, 8(4), 78-84. https://doi.org/10.33844/ijol.2019.60392

Astin, J., Jenkins, T., \& Moore, L. (2002). Medical students' perspective on the teaching of medical statistics in the undergraduate medical curriculum. Statistics in Medicine, 21(7), 1003-1006; discussion 1007. https://doi.org/10.1002/sim.1132

Balendran, K., \& John, L. (2017). COMPARISON OF LEARNING OUTCOMES IN PROBLEM BASED LEARNING AND LECTURE BASED LEARNING IN TEACHING FORENSIC MEDICINE. JOURNAL OF EVOLUTION OF MEDICAL AND DENTAL SCIENCES-JEMDS, 6(2), 89-92. https://doi.org/10.14260/jemds/2017/22

Berger, C., Brinkrolf, P., Ertmer, C., Becker, J., Friederichs, H., Wenk, M., Van Aken, H., \& Hahnenkamp, K. (2019). Combination of problem-based learning with high-fidelity simulation in CPR training improves short and long-term CPR skills: a randomised single blinded trial. BMC MEDICAL EDUCATION, 19. https://doi.org/10.1186/s12909-019-1626-7

BERNSTEIN, P., TIPPING, J., BERCOVITZ, K., \& SKINNER, H. A. (1995). SHIFTING STUDENTS AND FACULTY TO A PBL CURRICULUM - ATTITUDES CHANGED AND LESSONS LEARNED. ACADEMIC MEDICINE, 7O(3), 245-247. https://doi.org/10.1097/00001888-199503000-00019

Blake, R. L., \& Parkison, L. (1998). Faculty evaluation of the clinical performances of students in a problem-based learning curriculum. TEACHING AND LEARNING IN MEDICINE, 10(2), 69-73. https://doi.org/10.1207/S15328015TLM1002\_3

BLOSSER, A., \& JONES, B. (1991). PROBLEM-BASED LEARNING IN A SURGERY CLERKSHIP. MEDICAL TEACHER, 13(4), $289-293$. https://doi.org/10.3109/01421599109089907

Bodagh N, Bloomfield J, Birch P \& Ricketts W (2017). Problem-based learning: a review. Br J Hosp Med (Lond), 78, C167-C170. doi:10.12968/hmed.2017.78.11.C167.

Bosch-Barrera, J., Briceno Garcia, H. C., Capella, D., De Castro Vila, C., Farres, R., Quintanas, A., Ramis, J., Roca, R., \& Brunet, J. (2015). TEACHING BIOETHICS TO STUDENTS OF MEDICINE WITH PROBLEM-BASED LEARNING (PBL). CUADERNOS DE BIOETICA, 26(87), 303-309.

Branda LA. (2013) El abc del ABP: Lo esencial del aprendizaje basado en problemas. (In Fundación Dr. Esteve, Cuadernos de la fundación Dr. Antonio Esteve $\mathrm{n}^{\circ} 27$ : El aprendizaje basado en problemas en sus textos, (pp.1-16). Barcelona).

Brewer, D. W. (2001). Endocrine PBL in the year 2000. Advances in Physiology Education, 25(1-4), 249-255. https://doi.org/10.1152/advances.2001.25.4.249

Brynhildsen, J., Dahle, L. O., Behrbohm Fallsberg, M., Rundquist, I., \& Hammar, M. (2002). Attitudes among students and teachers on vertical integration between clinical medicine and basic science within a problem-based undergraduate medical curriculum. Medical Teacher, 24(3), 286-288.

https://doi.org/10.1080/01421590220134105

Bui-Mansfield, L. T., \& Chew, F. S. (2001). Radiologists as clinical tutors in a problem-based medical school curriculum. Academic Radiology, 8(7), $657-663$. https://doi.org/10.1016/S1076-6332(03)80693-1 
Burgun, A., Darmoni, S., Le Duff, F., \& Weber, J. (2006). Problem-based learning in medical informatics for undergraduate medical students: An experiment in two medical schools. INTERNATIONAL JOURNAL OF MEDICAL INFORMATICS, 75(5), 396-402. https://doi.org/10.1016/j.ijmedinf.2005.07.014

Carrera, L. I., Tellez, T. E., \& D'Ottavio, A. E. (2003). Implementing a problem-based learning curriculum in an Argentinean medical school: Implications for developing countries. ACADEMIC MEDICINE, 78(8), 798-801. https://doi.org/10.1097/00001888-200308000-00010

Casassus, P., Hivon, R., Gagnayre, R., \& d'Ivernois, J. F. (1999). An initial experiment in haematology instruction using the problem-based learning method in third-year medical training in France. Hematology and Cell Therapy, 41(4), 137-144. https://doi.org/10.1007/s00282-999-0137-0

Casey, P. M., Magrane, D., \& Lesnick, T. G. (2005). Improved performance and student satisfaction after implementation of a problem-based preclinical obstetrics and gynecology curriculum. American Journal of Obstetrics and Gynecology, 193(5), 1874-1878. https://doi.org/10.1016/j.ajog.2005.07.061

Chang, B. J. (2016). Problem-based learning in medical school: A student's perspective. ANNALS OF MEDICINE AND SURGERY, 12, 88-89. https://doi.org/10.1016/j.amsu.2016.11.011

Chang, C.-H., Yang, C.-Y., See, L.-C., \& Lui, P.-W. (2004). High satisfaction with problem-based learning for anesthesia. Chang Gung Medical Journal, 27(9), 654662 .

Chang, G., Cook, D., Maguire, T., Skakun, E., Yakimets, W. W., \& Warnock, G. L. (1995). Problem-based learning: its role in undergraduate surgical education. Canadian Journal of Surgery. Journal Canadien de Chirurgie, 38(1), 13-21.

Chang, H.-C., Wang, N.-Y., Ko, W.-R., Yu, Y.-T., Lin, L.-Y., \& Tsai, H.-F. (2017). The effectiveness of clinical problem-based learning model of medico-jurisprudence education on general law knowledge for Obstetrics/Gynecological interns. Taiwanese Journal of Obstetrics \& Gynecology, 56(3), 325-330.

https://doi.org/10.1016/j.tjog.2017.04.011

Chng, E., Yew, E. H. J., \& Schmidt, H. G. (2015). To what extent do tutor-related behaviours influence student learning in PBL? Advances in Health Sciences Education: Theory and Practice, 20(1), 5-21. https://doi.org/10.1007/s10459-014-9503-y

Cohen-Schotanus, J., Muijtjens, A. M. M., Schoenrock-Adema, J., Geertsma, J., \& van der Vleuten, C. P. M. (2008). Effects of conventional and problem-based learning on clinical and general competencies and career development. MEDICAL EDUCATION, 42(3), 256-265. https://doi.org/10.1111/j.13652923.2007.02959.x

Collard, A., Gelaes, S., Vanbelle, S., Bredart, S., Defraigne, J.-O., Boniver, J., \& Bourguignon, J.-P. (2009). Reasoning versus knowledge retention and ascertainment throughout a problem-based learning curriculum. Medical Education, 43(9), 854-865. https://doi.org/10.1111/j.1365-2923.2009.03410.x

Curtis, J. A., Indyk, D., \& Taylor, B. (2001). Successful use of problem-based learning in a third-year pediatric clerkship. Ambulatory Pediatrics: The Official Journal of the Ambulatory Pediatric Association, 1(3), 132-135. https://doi.org/10.1367/1539-4409(2001)001<0132:suopbl>2.0.co;2

Dale E. (1932). Methods for Analyzing the Content of Motion Pictures. Journal of Educational Sociology, 6, 244-250.

DeLowerntal, E. (1996). An evaluation of a module in problem-based learning. INTERNATIONAL JOURNAL OF EDUCATIONAL DEVELOPMENT, 16(3), 303-307. https://doi.org/10.1016/0738-0593(96)00001-6

Demiroren, M., Turan, S., \& Oztuna, D. (2016). Medical students' self-efficacy in problem-based learning and its relationship with self-regulated learning. MEDICAL EDUCATION ONLINE, 21. https://doi.org/10.3402/meo.v21.30049

DESMARCHAIS, J. E. (1993). A STUDENT-CENTERED, PROBLEM-BASED CURRICULUM - 5 YEARS EXPERIENCE. CANADIAN MEDICAL ASSOCIATION JOURNAL, $148(9), 1567-1572$.

Ding, X., Zhao, L., Chu, H., Tong, N., Ni, C., Hu, Z., Zhang, Z., \& Wang, M. (2014). Assessing the effectiveness of problem-based learning of preventive medicine education in China. Scientific Reports, 4, 5126. https://doi.org/10.1038/srep05126

Distlehorst, L. H., Dawson, E., Robbs, R. S., \& Barrows, H. S. (2005). Problem-based learning outcomes: The glass half-full. ACADEMIC MEDICINE, 80(3), 294299. https://doi.org/10.1097/00001888-200503000-00020

Doig, K., \& Werner, E. (2000). The marriage of a traditional lecture-based curriculum and problem-based learning: are the offspring vigorous? MEDICAL TEACHER, 22(2), 173-178.

Dyke, P., Jamrozik, K., \& Plant, A. J. (2001). A randomized trial of a problem-based learning approach for teaching epidemiology. Academic Medicine: Journal of the Association of American Medical Colleges, 76(4), 373-379. https://doi.org/10.1097/00001888-200104000-00016

Eltony, S. A., El-Sayed, N. H., El-Araby, S. E.-S., \& Kassab, S. E. (2017). Implementation and Evaluation of a Patient Safety Course in a Problem-based Learning Program. EDUCATION FOR HEALTH, 3O(1), 44-49. https://doi.org/10.4103/1357-6283.210512

Elzubeir, M. A. (2012). Teaching of the renal system in an integrated, problem-based curriculum. Saudi Journal of Kidney Diseases and Transplantation: An Official Publication of the Saudi Center for Organ Transplantation, Saudi Arabia, 23(1), 93-98. http://www.ncbi.nlm.nih.gov/pubmed/22237226

Page $7 / 34$ 
Farrell, T. A., Albanese, M. A., \& Pomrehn, P. R. J. (1999). Problem-based learning in ophthalmology: a pilot program for curricular renewal. Archives of Ophthalmology (Chicago, III. : 1960), 117(9), 1223-1226. https://doi.org/10.1001/archopht.117.9.1223

Finch, P. N. (1999). The effect of problem-based learning on the academic performance of students studying podiatric medicine in Ontario. MEDICAL EDUCATION, 33(6), 411-417.

Ghosh, S., \& Dawka, V. (2000). Combination of didactic lecture with problem-based learning sessions in physiology teaching in a developing medical college in Nepal. ADVANCES IN PHYSIOLOGY EDUCATION, 24(1), 8-12.

Gonzalez Mirasol, E., Gomez Garcia, M. T., Lobo Abascal, P., Moreno Selva, R., Fuentes Rozalen, A. M., \& Gonzalez Merlo, G. (2015). Analysis of perception of training in graduates of the Faculty of Medicine at Universidad de Castilla-Mancha. EVALUATION AND PROGRAM PLANNING, 52, $169-175$.

https://doi.org/10.1016/j.evalprogplan.2015.06.001

Gresham, C. L., \& Philp, J. R. (1996). Problem-based learning in clinical medicine. TEACHING AND LEARNING IN MEDICINE, 8(2), $111-115$. https://doi.org/10.1080/10401339609539776

Griffith, C. D., Blue, A. V, Mainous, A. G., \& DeSimone, P. A. (1996). Housestaff attitudes toward a problem-based clerkship. MEDICAL TEACHER, $18(2), 133-134$. https://doi.org/10.3109/01421599609034147

Grisham, J. W., Martiniuk, A. L. C., Negin, J., \& Wright, E. P. (2015). Problem-based learning (PBL) and public health: an initial exploration of perceptions of PBL in Vietnam. Asia-Pacific Journal of Public Health, 27(2), NP2019-27. https://doi.org/10.1177/1010539512436875

Grkovic, I. (2005). Transition of the medical curriculum from classical to integrated: Problem-based approach and Australian way of keeping academia in medicine. CROATIAN MEDICAL JOURNAL, 46(1), 16-20.

Gurpinar, E., Musal, B., Aksakoglu, G., \& Ucku, R. (2005). Comparison of knowledge scores of medical students in problem-based learning and traditional curriculum on public health topics. BMC Medical Education, 5(1), 7. https://doi.org/10.1186/1472-6920-5-7

Gurpinar, E., Senol, Y., \& Aktekin, M. R. (2009). Evaluation of Problem Based Learning by Tutors and Students in a Medical Faculty of Turkey. KUWAIT MEDICAL JOURNAL, 41(2), 123-127.

Hande, S., Mohammed, C. A., \& Komattil, R. (2015). Acquisition of knowledge, generic skills and attitudes through problem-based learning: Student perspectives in a hybrid curriculum. JOURNAL OF TAIBAH UNIVERSITY MEDICAL SCIENCES, 10(1, SI), 21-25. https://doi.org/10.1016/j.jtumed.2014.01.008

Hill, J., Rolfe, I. E., Pearson, S. A., \& Heathcote, A. (1998). Do junior doctors feel they are prepared for hospital practice? A study of graduates from traditional and non-traditional medical schools. MEDICAL EDUCATION, 32(1), 19-24. https://doi.org/10.1046/j.1365-2923.1998.00152.x

Hincapie Parra, D. A., Ramos Monobe, A., \& Chrino-Barcelo, V. (2018). Problem Based Learning as an Active Learning strategy and its impact on academic performance and critical thinking of Medical students. REVISTA COMPLUTENSE DE EDUCACION, 29(3), 665-681. https://doi.org/10.5209/RCED.53581

Hmelo, C. E. (1998). Problem-based learning: Effects on the early acquisition of cognitive skill in medicine. JOURNAL OF THE LEARNING SCIENCES, 7(2), 173208. https://doi.org/10.1207/s15327809jls0702\_2

Hoffman, K., Hosokawa, M., Blake Jr., R., Headrick, L., \& Johnson, G. (2006). Problem-based learning outcomes: Ten years of experience at the University of Missouri-Columbia School of Medicine. ACADEMIC MEDICINE, 81(7), 617-625. https://doi.org/10.1097/01.ACM.0000232411.97399.c6

Hoover, C. R., Wong, C. C., \& Azzam, A. (2012). From primary care to public health: using Problem-based Learning and the ecological model to teach public health to first year medical students. Journal of Community Health, 37(3), 647-652. https://doi.org/10.1007/s10900-011-9495-y

Hu, X., Zhang, H., Song, Y., Wu, C., Yang, Q., Shi, Z., Zhang, X., \& Chen, W. (2019). Implementation of flipped classroom combined with problem-based learning: an approach to promote learning about hyperthyroidism in the endocrinology internship. BMC Medical Education, 19(1), 290. https://doi.org/10.1186/s12909019-1714-8

Johnston, J. M., Schooling, C. M., \& Leung, G. M. (2009). A randomised-controlled trial of two educational modes for undergraduate evidence-based medicine learning in Asia. BMC Medical Education, 9, 63. https://doi.org/10.1186/1472-6920-9-63

Kalaian, H. A., \& Mullan, P. B. (1996). Exploratory factor analysis of students' ratings of a problem-based learning curriculum. ACADEMIC MEDICINE, 71(4), 390-392. https://doi.org/10.1097/00001888-199604000-00019

Kaufman, D. M., \& Mann, K. V. (1996). Comparing students' attitudes in problem-based and conventional curricula. ACADEMIC MEDICINE, 71(10), 1096-1099. https://doi.org/10.1097/00001888-199610000-00018

Kaufman, D. M., \& Mann, K. V. (1998). Comparing achievement on the Medical Council of Canada Qualifying Examination Part I of students in conventional and problem-based learning curricula. ACADEMIC MEDICINE, 73(11), 1211-1213. https://doi.org/10.1097/00001888-199811000-00022

Kaufman, D. M., \& Mann, K. V. (1999). Achievement of Students in a Conventional and Problem-Based Learning (PBL) Curriculum. ADVANCES IN HEALTH SCIENCES EDUCATION, 4(3), 245-260. https://doi.org/10.1023/A:1009829831978

Page $8 / 34$ 
Kelly, A. M. (2000). A problem-based learning resource in emergency medicine for medical students. Journal of Accident \& Emergency Medicine, 17(5), 320323. https://doi.org/10.1136/emj.17.5.320

Kemahli, S. (2005). Hematology education in a problem-based curriculum. Hematology (Amsterdam, Netherlands), 10 Suppl 1, $161-163$. https://doi.org/10.1080/10245330512331390267

Khan, I. A., \& Al-Swailmi, F. K. (2015). Perceptions of faculty and students regarding Problem Based Learning: A mixed methods study. JOURNAL OF THE PAKISTAN MEDICAL ASSOCIATION, 65(12), 1334-1338.

Khoo, H. E., Chhem, R. K., Gwee, M. C. E., \& Balasubramaniam, P. (2001). Introduction of problem-based learning in a traditional medical curriculum in Singapore - Students' and tutors' perspectives. ANNALS ACADEMY OF MEDICINE SINGAPORE, 30(4), 371-374.

Khoshnevisasl, P., Sadeghzadeh, M., Mazloomzadeh, S., Feshareki, R. H., \& Ahmadiafshar, A. (2014). Comparison of Problem-based Learning With Lecturebased Learning. IRANIAN RED CRESCENT MEDICAL JOURNAL, 16(5). https://doi.org/10.5812/ircmj.5186

Kong, J., Li, X., Wang, Y., Sun, W., \& Zhang, J. (2009). Effect of digital problem-based learning cases on student learning outcomes in ophthalmology courses. Archives of Ophthalmology (Chicago, III. : 1960), 127(9), 1211-1214. https://doi.org/10.1001/archophthalmol.2009.110

Korkmaz, N. S., \& Ozcelik, S. (2020). Evaluation of the Opinions of the First, Second and Third Term Medical Students About Problem Based Learning Sessions in Bezmialem Vakif University. BEZMIALEM SCIENCE, 8(2), 144-149. https://doi.org/10.14235/bas.galenos.2019.3471

Leung, G. M., Lam, T. H., \& Hedley, A. J. (2001). Problem-based public health learning - from the classroom to the community. Medical Education, 35(11), $1071-1072$.

Levac D, Colquhoun H, \& O’Brien KK. (2010). Scoping studies: Advancing the methodology. Implementation Science, 5(1), 69. doi:10.1186/1748-5908-5-69

Li, J., Li, Q. L., Li, J., Chen, M. L., Xie, H. F., Li, Y. P., \& Chen, X. (2013). Comparison of three problem-based learning conditions (real patients, digital and paper) with lecture-based learning in a dermatology course: a prospective randomized study from China. Medical Teacher, 35(2), e963-70.

https://doi.org/10.3109/0142159X.2012.719651

Li, X., Xie, F., Li, X., Li, G., Chen, X., Lv, J., \& Peng, C. (2020). Development, application, and evaluation of a problem-based learning method in clinical laboratory education. CLINICA CHIMICA ACTA, 510, 681-684. https://doi.org/10.1016/j.cca.2020.08.037

Lin, Y.-C., Huang, Y.-S., Lai, C.-S., Yen, J.-H., \& Tsai, W.-C. (2009). PROBLEM-BASED LEARNING CURRICULUM IN MEDICAL EDUCATION AT KAOHSIUNG MEDICAL UNIVERSITY. KAOHSIUNG JOURNAL OF MEDICAL SCIENCES, 25(5), 264-269. https://doi.org/10.1016/S1607-551X(09)70072-5

Liu, C.-X., Ouyang, W.-W., Wang, X.-W., Chen, D., \& Jiang, Z.-L. (2020). Comparing hybrid problem-based and lecture learning (PBL plus LBL) with LBL pedagogy on clinical curriculum learning for medical students in China: a meta-analysis of randomized controlled trials. MEDICINE, 99(16).

https://doi.org/10.1097/MD.0000000000019687

Lucas, M., García Guasch, R., Moret, E., Llasera, R., Melero, A., \& Canet, J. (2006). [Problem-based learning in an undergraduate medical school course on anesthesiology, recovery care, and pain management]. Revista espanola de anestesiologia y reanimacion, 53(7), 419-425.

Ma, Y., \& Lu, X. (2019). The effectiveness of problem-based learning in pediatric medical education in China: A meta-analysis of randomized controlled trials. Medicine, 98(2), e14052. https://doi.org/10.1097/MD.0000000000014052

Macallan, D. C., Kent, A., Holmes, S. C., Farmer, E. A., \& McCrorie, P. (2009). A model of clinical problem-based learning for clinical attachments in medicine. MEDICAL EDUCATION, 43(8), 799-807. https://doi.org/10.1111/j.1365-2923.2009.03406.x

Margolius, S. W., Papp, K. K., Altose, M. D., \& Wilson-Delfosse, A. L. (2020). Students perceive skills learned in pre-clerkship PBL valuable in core clinical rotations. MEDICAL TEACHER, 42(8), 902-908. https://doi.org/10.1080/0142159X.2020.1762031

McGrew, M. C., Skipper, B., Palley, T., \& Kaufman, A. (1999). Student and faculty perceptions of problem-based learning on a family medicine clerkship. Family Medicine, 31(3), 171-176.

McLean, M. (2004). A comparison of students who chose a traditional or a problem-based learning curriculum after failing year 2 in the traditional curriculum: A unique case study at the Nelson R. Mandela School of Medicine. TEACHING AND LEARNING IN MEDICINE, 16(3), 301-303.

https://doi.org/10.1207/s15328015tlm1603\_15

McParland, M., Noble, L. M., \& Livingston, G. (2004). The effectiveness of problem-based learning compared to traditional teaching in undergraduate psychiatry. Medical Education, 38(8), 859-867. https://doi.org/10.1111/j.1365-2929.2004.01818.x

MENNIN, S. P., FRIEDMAN, M., SKIPPER, B., KALISHMAN, S., \& SNYDER, J. (1993). PERFORMANCES ON THE NBME-I, NBME-II, AND NBME-III BY MEDICALSTUDENTS IN THE PROBLEM-BASED LEARNING AND CONVENTIONAL TRACKS AT THE UNIVERSITY-OF-NEW-MEXICO. ACADEMIC MEDICINE, 68(8), 616624. https://doi.org/10.1097/00001888-199308000-00012 
Meo, S. A. (2014). Undergraduate medical student's perceptions on traditional and problem based curricula: Pilot study. JOURNAL OF THE PAKISTAN MEDICAL ASSOCIATION, 64(7), 775-779.

Miller GE (1990). The assessment of clinical skills/competence/performance. Academic Medicine, S63-7.

Mpalanyi, M., Nalweyiso, I. D., \& Mubuuke, A. G. (2020). Perceptions of radiography students toward problem-based learning almost two decades after its introduction at Makerere University, Uganda. Journal of Medical Imaging and Radiation Sciences, 51(4), 639-644. https://doi.org/10.1016/j.jmir.2020.06.009

Mughal, A. M., \& Shaikh, S. H. (2018). Assessment of collaborative problem solving skills in Undergraduate Medical Students at Ziauddin College of Medicine, Karachi. PAKISTAN JOURNAL OF MEDICAL SCIENCES, 34(1), 185-189. https://doi.org/10.12669/pjms.341.13485

Navarro H, N., \& Zamora S, J. (2014). The opinion of teachers about tutorial problem based learning. REVISTA MEDICA DE CHILE, $142(8), 989-997$. https://doi.org/10.4067/S0034-98872014000800006

Norman, G. R., Wenghofer, E., \& Klass, D. (2008). Predicting doctor performance outcomes of curriculum interventions: problem-based learning and continuing competence. MEDICAL EDUCATION, 42(8), 794-799. https://doi.org/10.1111/j.1365-2923.2008.03131.x

Nosair, E., Mirghani, Z., \& Mostafa, R. M. (2015). Measuring Students' Perceptions of Educational Environment in the PBL Program of Sharjah Medical College. JOURNAL OF MEDICAL EDUCATION AND CURRICULAR DEVELOPMENT, 2, 71-79. https://doi.org/10.4137/JMECDECDECD.S29926

Nouns, Z., Schauber, S., Witt, C., Kingreen, H., \& Schuettpelz-Brauns, K. (2012). Development of knowledge in basic sciences: a comparison of two medical curricula. MEDICAL EDUCATION, 46(12), 1206-1214. https://doi.org/10.1111/medu.12047

Pham MT, Rajic' A, Greig JD, Sargeant JM, Papadopoulos A \& McEwen SA (2014). A scoping review of scoping reviews: Advancing the approach and enhancing the consistency. Research Synthesis Methods, 5(4), 371-385. doi:10.1002/jrsm.1123.

Purdy, R. A., Benstead, T. J., Holmes, D. B., \& Kaufman, D. M. (1999). Using problem-based learning in neurosciences education for medical students. CANADIAN JOURNAL OF NEUROLOGICAL SCIENCES, 26(3), 211-216. https://doi.org/10.1017/S0317167100000287

Richards, B. F., Ober, K. P., CariagoLo, L., Camp, M. G., Philp, J., McFarlane, M., Rupp, R., \& Zaccaro, D. J. (1996). Ratings of students' performances in a thirdyear internal medicine clerkship: A comparison between problem-based and lecture-based curricula. ACADEMIC MEDICINE, 71(2), 187-189.

https://doi.org/10.1097/00001888-199602000-00028

Salinas Sánchez, A. S., Hernández Millán, I., Virseda Rodríguez, J. A., Segura Martín, M., Lorenzo Romero, J. G., Giménez Bachs, J. M., Donate Moreno, M. J., Ruiz Mondéjar, R., Cañamares Pabolaza, L., Polo Ruiz, L., Pastor Guzmán, J. M., Martínez Córcoles, B., \& Martínez Martín, M. (2005). [Problem-based learning in urology training. The Faculty of Medicine of the Universidad de Castilla-La Mancha model]. Actas urologicas espanolas, 29(1), 8-15.

https://doi.org/10.1016/s0210-4806(05)73193-4

Saloojee, S., \& van Wyk, J. (2012). The impact of a problem-based learning curriculum on the psychiatric knowledge and skills of final-year students at the Nelson R Mandela School of Medicine. SOUTH AFRICAN JOURNAL OF PSYCHIATRY, 18(3), 116.

SCHWARTZ, R. W., DONNELLY, M. B., NASH, P. P., \& YOUNG, B. (1992). DEVELOPING STUDENTS COGNITIVE SKILLS IN A PROBLEM-BASED SURGERY CLERKSHIP. ACADEMIC MEDICINE, 67(10), 694-696. https://doi.org/10.1097/00001888-199210000-00016

Seneviratne, R. D., Samarasekera, D. D., Karunathilake, I. M., \& Ponnamperuma, G. G. (2001). Students' perception of problem-based learning in the medical curriculum of the Faculty of Medicine, University of Colombo. ANNALS ACADEMY OF MEDICINE SINGAPORE, 30(4), 379-381.

Shanley P. F. (2007). Viewpoint: leaving the "empty glass" of problem-based learning behind: new assumptions and a revised model for case study in preclinical medical education. Academic medicine: journal of the Association of American Medical Colleges, 82(5), 479-485.

https://doi.org/10.1097/ACM.0b013e31803eac4c

SOKAS, R. K., DISERENS, D., \& JOHNSTON, M. A. (1990). INTEGRATING OCCUPATIONAL-HEALTH INTO THE INTERNAL MEDICINE CLERKSHIP USING PROBLEM-BASED LEARNING. CLINICAL RESEARCH, 38(2), A735.

Steadman, R. H., Coates, W. C., Huang, Y. M., Matevosian, R., Larmon, B. R., McCullough, L., \& Ariel, D. (2006). Simulation-based training is superior to problembased learning for the acquisition of critical assessment and management skills. CRITICAL CARE MEDICINE, 34(1), $151-157$.

https://doi.org/10.1097/01.CCM.0000190619.42013.94

Subramaniam, R. M., Scally, P., \& Gibson, R. (2004). Problem-based learning and medical student radiology teaching. Australasian Radiology, 48(3), 335-338. https://doi.org/10.1111/j.0004-8461.2004.01317.x

Sulaiman, N., \& Hamdy, H. (2013). Problem-based learning: where are we now? Guide supplement 36.3-Practical Application. Medical Teacher, 35(2), 160162. https://doi.org/10.3109/0142159X.2012.737965

Suleman, W., Iqbal, R., Alsultan, A., \& Baig, S. M. (2010). Perception of 4(th) year Medical students about Problem Based Learning. PAKISTAN JOURNAL OF MEDICAL SCIENCES, 26(4), 871-874. 
Tamblyn, R., Abrahamowicz, M., Dauphinee, D., Girard, N., Bartlett, G., Grand'Maison, P., \& Brailovsky, C. (2005). Effect of a community oriented problem based learning curriculum on quality of primary care delivered by graduates: historical cohort comparison study. BMJ (Clinical Research Ed.), 331 (7523), 1002. https://doi.org/10.1136/bmj.38636.582546.7C

Thompson, K. L., Gendreau, J. L., Strickling, J. E., \& Young, H. E. (2019). Cadaveric Dissection in Relation to Problem-Based Learning Case Sequencing: A Report of Medical Student Musculoskeletal Examination Performances and Self-Confidence. ANATOMICAL SCIENCES EDUCATION, 12(6), $619-626$. https://doi.org/10.1002/ase.1891

Tian, J.-H., Yang, K.-H., \& Liu, A.-P. (2012). Problem-based learning in evidence-based medicine courses at Lanzhou University. In Medical teacher (Vol. 34, Issue 4, p. 341). https://doi.org/10.3109/0142159X.2011.531169

Tousignant, M., \& DesMarchais, J. E. (2002). Accuracy of student self-assessment ability compared to their own performance in a problem-based learning medical program: A correlation study. ADVANCES IN HEALTH SCIENCES EDUCATION, 7(1), 19-27. https://doi.org/10.1023/A:1014516206120

Trevena, L. J., \& Clarke, R. M. (2002). Self-directed learning in population health. a clinically relevant approach for medical students. American Journal of Preventive Medicine, 22(1), 59-65. https://doi.org/10.1016/s0749-3797(01)00395-6

Tricco AC, Lillie E, Zarin W, O'Brien KK, Colquhoun H, Levac D, et al. (2018). PRISMA extensión for scoping reviews (PRISMA-ScR): Checklist and explanation. Annals of Internal Medicine. https ://doi.org/10.7326/M18-0850.

Tsou, K.-I., Cho, S.-L., Lin, C.-S., Sy, L. B., Yang, L.-K., Chou, T.-Y., \& Chiang, H.-S. (2009). SHORT-TERM OUTCOMES OF A NEAR-FULL PBL CURRICULUM IN A NEW TAIWAN MEDICAL SCHOOL. KAOHSIUNG JOURNAL OF MEDICAL SCIENCES, 25(5), 282-292. https://doi.org/10.1016/S1607-551X(09)70075-0

Tshitenge, S. T., Ndhlovu, C. E., \& Ogundipe, R. (2017). Evaluation of problem-based learning curriculum implementation in a clerkship rotation of a newly established African medical training institution: lessons from the University of Botswana. The Pan African medical journal, $27,13$.

https://doi.org/10.11604/pamj.2017.27.13.10623

Tufts, M. A., \& Higgins-Opitz, S. B. (2009). What makes the learning of physiology in a PBL medical curriculum challenging? Student perceptions. ADVANCES IN PHYSIOLOGY EDUCATION, 33(3), 187-195. https://doi.org/10.1152/advan.90214.2008

Urrutia Aguilar, M. E., Hamui-Sutton, A., Castaneda Figueiras, S., van der Goes, T. I., \& Guevara-Guzman, R. (2011). Impact of problem-based learning on the cognitive processes of medical students. GACETA MEDICA DE MEXICO, 147(5), 385-393.

USHERWOOD, T., JOESBURY, H., \& HANNAY, D. (1991). STUDENT-DIRECTED PROBLEM-BASED LEARNING IN GENERAL-PRACTICE AND PUBLIC-HEALTH MEDICINE. MEDICAL EDUCATION, 25(5), 421-429. https://doi.org/10.1111/j.1365-2923.1991.tb00090.x

Vernon, D. T. A., \& Hosokawa, M. C. (1996). Faculty attitudes and opinions about problem-based learning. ACADEMIC MEDICINE, 71(11), 1233-1238. https://doi.org/10.1097/00001888-199611000-00020

Villamor, M. C. A. (2001). Problem-based learning (PBL) as an approach in the teaching of biochemistry of the endocrine system at the Angeles University College of Medicine. ANNALS ACADEMY OF MEDICINE SINGAPORE, 30(4), 382-386.

Vincelette, J., Lalande, R., Delorme, P., Goudreau, J., Lalonde, V., \& Jean, P. (1997). A pilot course as a model for implementing a PBL curriculum. ACADEMIC MEDICINE, 72(8), 698-701. https://doi.org/10.1097/00001888-199708000-00015

Walters, M. R. (2001). Problem-based learning within endocrine physiology lectures. Advances in Physiology Education, 25(1-4), $225-227$. https://doi.org/10.1152/advances.2001.25.4.225

Wang, J., Zhang, W., Qin, L., Zhao, J., Zhang, S., Gu, J., \& Zhou, C. (2010). Problem-Based Learning in Regional Anatomy Education at Peking University. ANATOMICAL SCIENCES EDUCATION, 3(3), 121-126. https://doi.org/10.1002/ase.151

Wenk, M., Waurick, R., Schotes, D., Wenk, M., Gerdes, C., Van Aken, H. K., \& Pöpping, D. M. (2009). Simulation-based medical education is no better than problem-based discussions and induces misjudgment in self-assessment. Advances in Health Sciences Education: Theory and Practice, 14(2), $159-171$. https://doi.org/10.1007/s10459-008-9098-2

Whitfield, C. R., Manger, E. A., Zwicker, J., \& Lehman, E. B. (2002). Differences between students in problem-based and lecture-based curricula measured by clerkship performance ratings at the beginning of the third year. TEACHING AND LEARNING IN MEDICINE, 14(4), 211-217.

https://doi.org/10.1207/S15328015TLM1404\_2

Yadav, R. L., Piryani, R. M., Deo, G. P., Shah, D. K., Yadav, L. K., \& Islam, M. N. (2018). Attitude and perception of undergraduate medical students toward the problem-based learning in Chitwan Medical College, Nepal. ADVANCES IN MEDICAL EDUCATION AND PRACTICE, 9, $317-322$.

https://doi.org/10.2147/AMEP.S160814

Yanamadala, M., Kaprielian, V. S., O’Connor Grochowski, C., Reed, T., \& Heflin, M. T. (2018). A problem-based learning curriculum in geriatrics for medical students. Gerontology \& Geriatrics Education, 39(2), 122-131. https://doi.org/10.1080/02701960.2016.1152268 
Yoo, D. M., Cho, A. R., \& Kim, S. (2019). Satisfaction with and suitability of the problem-based learning program at the Catholic University of Korea College of Medicine. JOURNAL OF EDUCATIONAL EVALUATION FOR HEALTH PROFESSIONS, 16. https://doi.org/10.3352/jeehp.2019.16.20

Zhang, S., Xu, J., Wang, H., Zhang, D., Zhang, Q., \& Zou, L. (2018). Effects of problem-based learning in Chinese radiology education: A systematic review and meta-analysis. Medicine, 97(9), e0069. https://doi.org/10.1097/MD.0000000000010069

Zhao, W., He, L., Deng, W., Zhu, J., Su, A., \& Zhang, Y. (2020). The effectiveness of the combined problem-based learning (PBL) and case-based learning (CBL) teaching method in the clinical practical teaching of thyroid disease. BMC MEDICAL EDUCATION, 20(1). https://doi.org/10.1186/s12909-020-02306-y

\section{Tables}


Table 1

Characteristics of the 124 publications included in the scoping review

Characteristic of the publication

Year of publication

Continents and countries ${ }^{a}$
$1990-1999$

2000-2009

2010-2021

Asia

\section{Number (percentage)}

$27(22 \%)$

$46(37 \%)$

$51(41 \%)$

$45(36.3 \%)$

China (16), Saudi Arabia (12), Egypt, India, Nepal and United Arab Emirates (2) and other ${ }^{b}$ nine countries (1)

North America

$39(31.5 \%)$

United States of America (27) and Canada (12)

Europe

$22(17.7 \%)$

Turkey (5), Germany and United Kingdom (4), Spain (3), France (2) and other ${ }^{\mathrm{C}}$ four countries (1)

Africa

$7(5.6 \%)$

South Africa (4), Botswana, Ghana and Uganda (1)

Oceania

$6(4.8 \%)$

Australia (5) and New Zealand (1)

South America

\section{$5(4.0 \%)$}

México (2), Argentina, Chile and Trinidad \& Tobago (1)

\begin{tabular}{|c|c|c|}
\hline \multirow[t]{4}{*}{ Study population } & Students & $94(75.8 \%)$ \\
\hline & Students and tutors & $16(12.9 \%)$ \\
\hline & Tutors & $6(4.8 \%)$ \\
\hline & Not specified & $8(6.5 \%)$ \\
\hline \multirow[t]{7}{*}{ Study design } & Survey or questionnaire & $45(36.3 \%)$ \\
\hline & Comparative non-randomized study & $32(25.8 \%)$ \\
\hline & Descriptive experience & $21(16.9 \%)$ \\
\hline & Comparative and randomized study & $16(12.9 \%)$ \\
\hline & Expert opinion, editorial or comment & $5(4.0 \%)$ \\
\hline & Systematic review and meta-analysis & $4(3.2 \%)$ \\
\hline & Narrative review & $1(0.8 \%)$ \\
\hline \multirow[t]{3}{*}{ Comparator } & Without comparison & $66(53.2 \%)$ \\
\hline & With traditional or lecture-based learning & $56(45.2 \%)$ \\
\hline & With simulation & $2(1.6 \%)$ \\
\hline \multirow[t]{6}{*}{ Main Outcome ${ }^{d}$} & Performance & $55(44.4 \%)$ \\
\hline & Student satisfaction & $33(26.6 \%)$ \\
\hline & Knowledge retention & $15(12.1 \%)$ \\
\hline & Not specified & $12(9.7 \%)$ \\
\hline & Tutor satisfaction & $5(4.0 \%)$ \\
\hline & Other & $4(3.2 \%)$ \\
\hline
\end{tabular}

${ }^{a}$ The number of publications of each country appears in parentheses. ${ }^{b}$ Including: Bahrain, Iran, South Korea, Pakistan, Philippines, Singapore, Sri Lanka, Taiwan and Vietnam. ' Including: Belgium, Georgia, Netherlands and Sweden. ${ }^{\mathrm{d}}$ Forty-five studies included secondary outcomes: including student satisfaction (23), tutor satisfaction (7), knowledge retention (5), social and/or communication skills (5), reasoning (1) and other outcomes (4). 
Table 2

Study subject of the 124 publications included in the scoping review

\begin{tabular}{|c|c|}
\hline Study subject & Number of publications \\
\hline Anatomy (one study including cadaveric dissection) & 2 \\
\hline Anesthesia & 3 \\
\hline Basic medical sciences & 1 \\
\hline Biochemistry & 2 \\
\hline Cardiopulmonary resuscitation & 1 \\
\hline Clinical laboratory & 1 \\
\hline Critical care skills & 1 \\
\hline Dermatology & 1 \\
\hline Emergency medicine & 1 \\
\hline Endocrinology (one study focused on thyroid surgery) & 5 \\
\hline Epidemiology & 1 \\
\hline Evidence-based medicine & 2 \\
\hline Family medicine & 2 \\
\hline Forensic medicine & 1 \\
\hline Geriatrics & 1 \\
\hline Hematology & 2 \\
\hline Internal Medicine & 2 \\
\hline Medical informatics & 1 \\
\hline Medical statistics & 1 \\
\hline Neurosciences & 1 \\
\hline Obstetrics and gynecology & 2 \\
\hline Occupational health & 1 \\
\hline Ophthalmology & 2 \\
\hline Otolaryngology & 1 \\
\hline Patient safety education program & 1 \\
\hline Pediatrics & 4 \\
\hline Pharmacology & 1 \\
\hline Physiology & 2 \\
\hline Preventive medicine & 2 \\
\hline Psychiatry & 2 \\
\hline Public health & 5 \\
\hline Radiology & 4 \\
\hline Renal system & 1 \\
\hline Respiratory & 1 \\
\hline Surgery & 4 \\
\hline Urology & 1 \\
\hline More than one discipline & 5 \\
\hline The global curriculum & 10 \\
\hline Not specified & 43 \\
\hline
\end{tabular}


Table 3

Study design according to main and secondary outcomes and continents

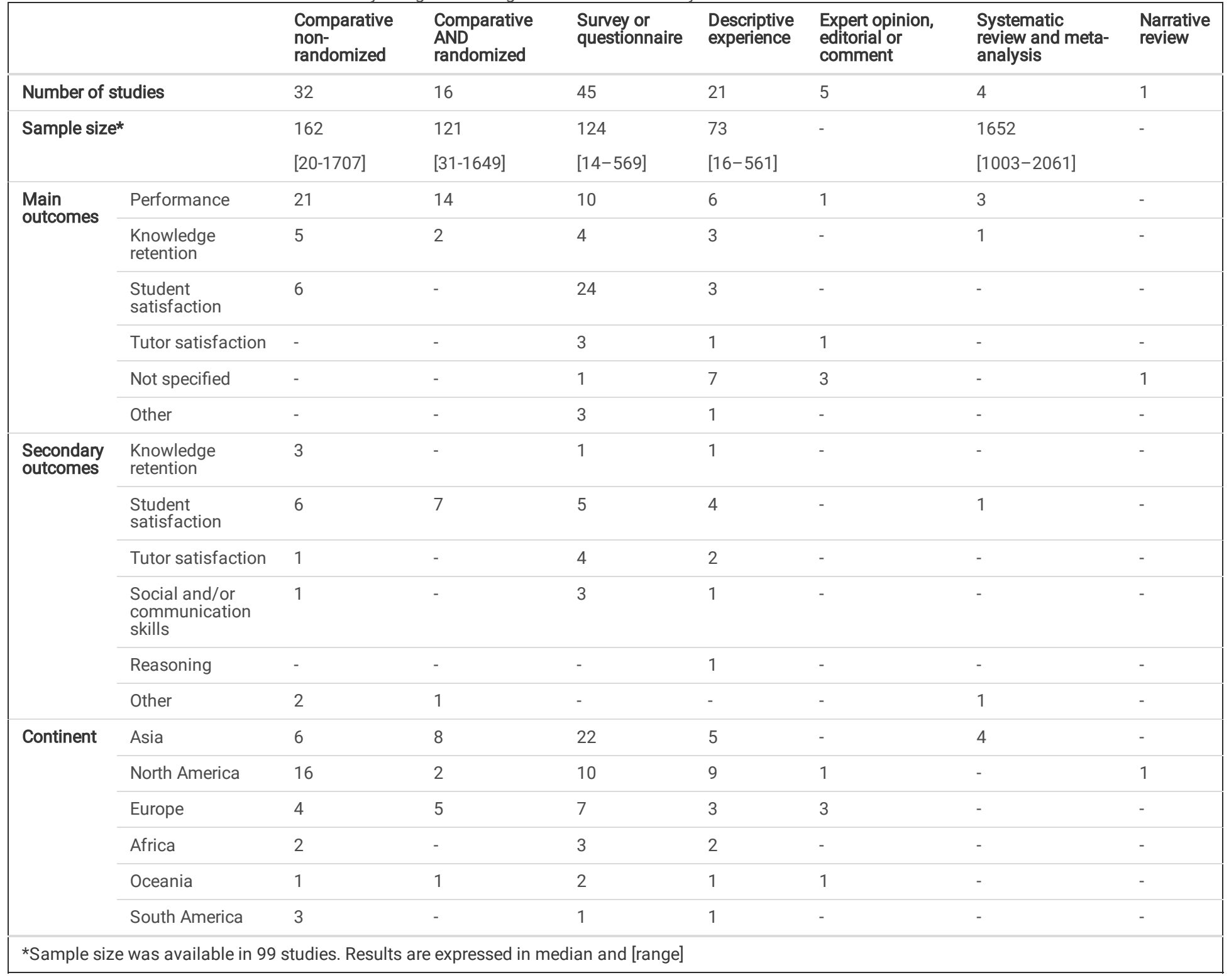


Table 4

Detailed characteristics and main results of the 124 included studies

\begin{tabular}{|lllllllll}
\hline Year & Author & Country & Continent & $\begin{array}{l}\text { Sample } \\
\text { size }\end{array}$ & $\begin{array}{l}\text { Study } \\
\text { population }\end{array}$ & $\begin{array}{l}\text { Design } \\
\text { /Methodology }\end{array}$ & Comparator & Study subject \\
\hline 1990 & Sokas & $\begin{array}{l}\text { United } \\
\text { States of } \\
\text { America }\end{array}$ & $\begin{array}{l}\text { America } \\
\text { (north) }\end{array}$ & 69 & Students & $\begin{array}{l}\text { Comparative } \\
\text { non- } \\
\text { randomized } \\
\text { study }\end{array}$ & $\begin{array}{l}\text { Traditional } \\
\text { or lecture }\end{array}$ & $\begin{array}{l}\text { Occupational } \\
\text { health }\end{array}$ \\
\hline
\end{tabular}

\begin{tabular}{|c|c|c|c|c|c|c|c|c|c|}
\hline 1991 & Blosser & $\begin{array}{l}\text { United } \\
\text { States of } \\
\text { America }\end{array}$ & $\begin{array}{l}\text { America } \\
\text { (north) }\end{array}$ & - & Students & $\begin{array}{l}\text { Descriptive } \\
\text { experience }\end{array}$ & None & Surgery & $\begin{array}{l}\text { Student } \\
\text { satisfaction }\end{array}$ \\
\hline
\end{tabular}

\begin{tabular}{|c|c|c|c|c|c|c|c|c|c|}
\hline 1991 & Usherwood & $\begin{array}{l}\text { United } \\
\text { Kingdom }\end{array}$ & Europe & 53 & Students & $\begin{array}{l}\text { Survey or } \\
\text { questionnaire }\end{array}$ & None & $\begin{array}{l}\text { General practice } \\
\text { and public health } \\
\text { medicine }\end{array}$ & $\begin{array}{l}\text { Student } \\
\text { satisfaction }\end{array}$ \\
\hline
\end{tabular}

\begin{tabular}{|c|c|c|c|c|c|c|c|c|c|c|}
\hline 1992 & Schwartz & $\begin{array}{l}\text { United } \\
\text { States of } \\
\text { America }\end{array}$ & $\begin{array}{l}\text { America } \\
\text { (north) }\end{array}$ & 57 & Students & $\begin{array}{l}\text { Comparative } \\
\text { non- } \\
\text { randomized } \\
\text { study }\end{array}$ & $\begin{array}{l}\text { Traditional } \\
\text { or lecture }\end{array}$ & Surgery & $\begin{array}{l}\text { Knowledge } \\
\text { retention }\end{array}$ & Other \\
\hline
\end{tabular}

\begin{tabular}{|c|c|c|c|c|c|c|c|c|c|}
\hline 1993 & Mennin & $\begin{array}{l}\text { United } \\
\text { States of } \\
\text { America }\end{array}$ & $\begin{array}{l}\text { America } \\
\text { (north) }\end{array}$ & 1649 & Students & $\begin{array}{l}\text { Comparative } \\
\text { and } \\
\text { randomized } \\
\text { study }\end{array}$ & $\begin{array}{l}\text { Traditional } \\
\text { or lecture }\end{array}$ & $\begin{array}{l}\text { The global } \\
\text { curriculum }\end{array}$ & Performance \\
\hline
\end{tabular}

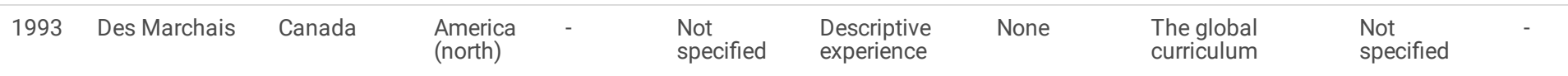




\begin{tabular}{|c|c|c|c|c|c|c|c|c|c|c|}
\hline Year & Author & Country & Continent & $\begin{array}{l}\text { Sample } \\
\text { size }\end{array}$ & $\begin{array}{l}\text { Study } \\
\text { population }\end{array}$ & $\begin{array}{l}\text { Design } \\
\text { /Methodology }\end{array}$ & Comparator & Study subject & Outcome & Outco \\
\hline 1995 & Chang & Canada & $\begin{array}{l}\text { America } \\
\text { (north) }\end{array}$ & - & Students & $\begin{array}{l}\text { Narrative } \\
\text { review }\end{array}$ & $\begin{array}{l}\text { Traditional } \\
\text { or lecture }\end{array}$ & Surgery & $\begin{array}{l}\text { Not } \\
\text { specified }\end{array}$ & - \\
\hline 1995 & Berntein & Canada & $\begin{array}{l}\text { America } \\
\text { (north) }\end{array}$ & 265 & $\begin{array}{l}\text { Students } \\
\text { and tutors }\end{array}$ & $\begin{array}{l}\text { Comparative } \\
\text { non- } \\
\text { randomized } \\
\text { study }\end{array}$ & $\begin{array}{l}\text { Traditional } \\
\text { or lecture }\end{array}$ & Not specified & $\begin{array}{l}\text { Student } \\
\text { satisfaction }\end{array}$ & $\begin{array}{l}\text { Tutor } \\
\text { satisf }\end{array}$ \\
\hline 1996 & Kaufman & Canada & $\begin{array}{l}\text { America } \\
\text { (north) }\end{array}$ & 168 & Students & $\begin{array}{l}\text { Comparative } \\
\text { non- } \\
\text { randomized } \\
\text { study }\end{array}$ & $\begin{array}{l}\text { Traditional } \\
\text { or lecture }\end{array}$ & $\begin{array}{l}\text { The global } \\
\text { curriculum }\end{array}$ & $\begin{array}{l}\text { Student } \\
\text { satisfaction }\end{array}$ & - \\
\hline 1996 & Richards & $\begin{array}{l}\text { United } \\
\text { States of } \\
\text { America }\end{array}$ & $\begin{array}{l}\text { America } \\
\text { (north) }\end{array}$ & 452 & Students & $\begin{array}{l}\text { Comparative } \\
\text { non- } \\
\text { randomized } \\
\text { study }\end{array}$ & $\begin{array}{l}\text { Traditional } \\
\text { or lecture }\end{array}$ & Internal Medicine & Performance & - \\
\hline 1996 & Kalaian & $\begin{array}{l}\text { United } \\
\text { States of } \\
\text { America }\end{array}$ & $\begin{array}{l}\text { America } \\
\text { (north) }\end{array}$ & 172 & Students & $\begin{array}{l}\text { Survey or } \\
\text { questionnaire }\end{array}$ & None & $\begin{array}{l}\text { Infectious } \\
\text { Diseases and } \\
\text { Cardiovascular }\end{array}$ & $\begin{array}{l}\text { Student } \\
\text { satisfaction }\end{array}$ & - \\
\hline 1996 & Gresham & $\begin{array}{l}\text { United } \\
\text { States of } \\
\text { America }\end{array}$ & $\begin{array}{l}\text { America } \\
\text { (north) }\end{array}$ & 64 & Students & $\begin{array}{l}\text { Descriptive } \\
\text { experience }\end{array}$ & None & Not specified & Performance & $\begin{array}{l}\text { Stude } \\
\text { satisf }\end{array}$ \\
\hline 1996 & Griffith & $\begin{array}{l}\text { United } \\
\text { States of } \\
\text { America }\end{array}$ & $\begin{array}{l}\text { America } \\
\text { (north) }\end{array}$ & 53 & Tutors & $\begin{array}{l}\text { Survey or } \\
\text { questionnaire }\end{array}$ & None & Internal Medicine & $\begin{array}{l}\text { Tutor } \\
\text { satisfaction }\end{array}$ & - \\
\hline
\end{tabular}




\begin{tabular}{|c|c|c|c|c|c|c|c|c|c|c|}
\hline Year & Author & Country & Continent & $\begin{array}{l}\text { Sample } \\
\text { size }\end{array}$ & $\begin{array}{l}\text { Study } \\
\text { population }\end{array}$ & $\begin{array}{l}\text { Design } \\
\text { /Methodology }\end{array}$ & Comparator & Study subject & Outcome & Outco \\
\hline 1996 & De Lowerntal & $\begin{array}{l}\text { South } \\
\text { Africa }\end{array}$ & Africa & - & $\begin{array}{l}\text { Students } \\
\text { and tutors }\end{array}$ & $\begin{array}{l}\text { Descriptive } \\
\text { experience }\end{array}$ & None & Not specified & $\begin{array}{l}\text { Tutor } \\
\text { satisfaction }\end{array}$ & $\begin{array}{l}\text { Stude } \\
\text { satisf: }\end{array}$ \\
\hline
\end{tabular}

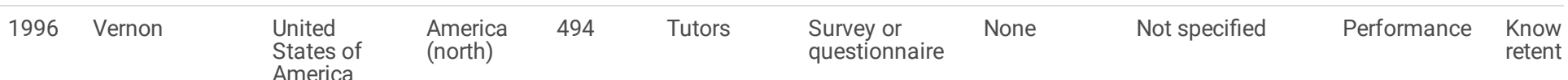

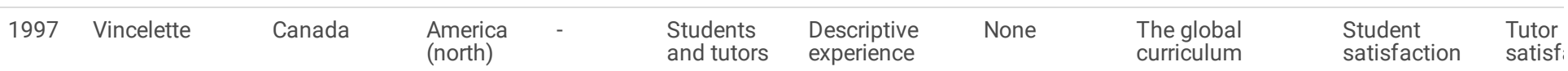

\begin{tabular}{|c|c|c|c|c|c|c|c|c|c|}
\hline 1998 & Kaufman & Canada & $\begin{array}{l}\text { America } \\
\text { (north) }\end{array}$ & 243 & Students & $\begin{array}{l}\text { Comparative } \\
\text { non- } \\
\text { randomized } \\
\text { study }\end{array}$ & $\begin{array}{l}\text { Traditional } \\
\text { or lecture }\end{array}$ & $\begin{array}{l}\text { The global } \\
\text { curriculum }\end{array}$ & Performance \\
\hline
\end{tabular}

1998 Hill Australia Oceania $139 \quad$ Students $\begin{aligned} & \begin{array}{l}\text { Comparative } \\ \text { non- } \\ \text { randomized } \\ \text { study }\end{array} \\ & \text { or lecture }\end{aligned}$

\begin{tabular}{|c|c|c|c|c|c|c|c|c|c|}
\hline 1998 & Blake & $\begin{array}{l}\text { United } \\
\text { States of } \\
\text { America }\end{array}$ & $\begin{array}{l}\text { America } \\
\text { (north) }\end{array}$ & 41 & Tutors & $\begin{array}{l}\text { Survey or } \\
\text { questionnaire }\end{array}$ & None & Not specified & Performance \\
\hline
\end{tabular}




\begin{tabular}{|c|c|c|c|c|c|c|c|c|c|c|}
\hline Year & Author & Country & Continent & $\begin{array}{l}\text { Sample } \\
\text { size }\end{array}$ & $\begin{array}{l}\text { Study } \\
\text { population }\end{array}$ & $\begin{array}{l}\text { Design } \\
\text { /Methodology }\end{array}$ & Comparator & Study subject & Outcome & Outco \\
\hline 1998 & Hmelo & $\begin{array}{l}\text { United } \\
\text { States of } \\
\text { America }\end{array}$ & $\begin{array}{l}\text { America } \\
\text { (north) }\end{array}$ & 76 & Students & $\begin{array}{l}\text { Comparative } \\
\text { non- } \\
\text { randomized } \\
\text { study }\end{array}$ & $\begin{array}{l}\text { Traditional } \\
\text { or lecture }\end{array}$ & Not specified & \multicolumn{2}{|c|}{ Knowledge retention } \\
\hline 1999 & Kaufman & Canada & $\begin{array}{l}\text { America } \\
\text { (north) }\end{array}$ & 243 & Students & $\begin{array}{l}\text { Comparative } \\
\text { non- } \\
\text { randomized } \\
\text { study }\end{array}$ & $\begin{array}{l}\text { Traditional } \\
\text { or lecture }\end{array}$ & $\begin{array}{l}\text { The global } \\
\text { curriculum }\end{array}$ & Performanc & $\begin{array}{l}\text { Stude } \\
\text { satisf }\end{array}$ \\
\hline
\end{tabular}

1999 Antepohl Germany Europe $123 \quad$ Students $\begin{aligned} & \begin{array}{l}\text { Comparative } \\ \text { and } \\ \text { randomized } \\ \text { study }\end{array} \\ & \begin{array}{l}\text { or lecture } \\ \text { stutisf }\end{array}\end{aligned}$

\begin{tabular}{|c|c|c|c|c|c|c|c|c|c|c|}
\hline 1999 & Finch & Canada & $\begin{array}{l}\text { America } \\
\text { (north) }\end{array}$ & 47 & Students & $\begin{array}{l}\text { Comparative } \\
\text { non- } \\
\text { randomized } \\
\text { study }\end{array}$ & $\begin{array}{l}\text { Traditional } \\
\text { or lecture }\end{array}$ & Pediatric & Performance & $\begin{array}{l}\text { Know } \\
\text { retent }\end{array}$ \\
\hline
\end{tabular}

\begin{tabular}{|c|c|c|c|c|c|c|c|c|c|c|}
\hline 1999 & McGrew & $\begin{array}{l}\text { United } \\
\text { States of } \\
\text { America }\end{array}$ & $\begin{array}{l}\text { America } \\
\text { (north) }\end{array}$ & - & $\begin{array}{l}\text { Students } \\
\text { and tutors }\end{array}$ & $\begin{array}{l}\text { Survey or } \\
\text { questionnaire }\end{array}$ & None & Family Medicine & $\begin{array}{l}\text { Not } \\
\text { specified }\end{array}$ & - \\
\hline
\end{tabular}

\begin{tabular}{|c|c|c|c|c|c|c|c|c|c|c|}
\hline 1999 & Casassus & France & Europe & 68 & Students & $\begin{array}{l}\text { Comparative } \\
\text { non- } \\
\text { randomized } \\
\text { study }\end{array}$ & $\begin{array}{l}\text { Traditional } \\
\text { or lecture }\end{array}$ & Hematology & Performance & $\begin{array}{l}\text { Stude } \\
\text { satisf: }\end{array}$ \\
\hline
\end{tabular}

\begin{tabular}{|c|c|c|c|c|c|c|c|c|c|c|}
\hline 1999 & Purdy & Canada & $\begin{array}{l}\text { America } \\
\text { (north) }\end{array}$ & - & Students & $\begin{array}{l}\text { Descriptive } \\
\text { experience }\end{array}$ & None & Neurosciences & Performance & $\begin{array}{l}\text { Stude } \\
\text { satisf: }\end{array}$ \\
\hline
\end{tabular}

\begin{tabular}{|c|c|c|c|c|c|c|c|c|c|c|}
\hline 1999 & Farrell & $\begin{array}{l}\text { United } \\
\text { States of } \\
\text { America }\end{array}$ & $\begin{array}{l}\text { America } \\
\text { (north) }\end{array}$ & 75 & Students & $\begin{array}{l}\text { Survey or } \\
\text { questionnaire }\end{array}$ & None & Ophthalmology & Performance & $\begin{array}{l}\text { Stude } \\
\text { satisf: }\end{array}$ \\
\hline
\end{tabular}




\begin{tabular}{|llllllllll}
\hline Year & Author & Country & Continent & $\begin{array}{l}\text { Sample } \\
\text { size }\end{array}$ & $\begin{array}{l}\text { Study } \\
\text { population }\end{array}$ & $\begin{array}{l}\text { Design } \\
\text { /Methodology }\end{array}$ & Comparator & Study subject & Outcome \\
\hline 2000 & Kelly & Australia & Oceania & - & Students & $\begin{array}{l}\text { Descriptive } \\
\text { experience }\end{array}$ & None & $\begin{array}{l}\text { Emergency } \\
\text { Medicine }\end{array}$ & $\begin{array}{l}\text { Not } \\
\text { specified }\end{array}$ \\
\hline
\end{tabular}

\begin{tabular}{|c|c|c|c|c|c|c|c|c|c|}
\hline 2000 & Doig & $\begin{array}{l}\text { United } \\
\text { States of } \\
\text { America }\end{array}$ & $\begin{array}{l}\text { America } \\
\text { (north) }\end{array}$ & - & $\begin{array}{l}\text { Not } \\
\text { specified }\end{array}$ & $\begin{array}{l}\text { Descriptive } \\
\text { experience }\end{array}$ & None & $\begin{array}{l}\text { The global } \\
\text { curriculum }\end{array}$ & $\begin{array}{l}\text { Not } \\
\text { specified }\end{array}$ \\
\hline
\end{tabular}

2000 Ghosh Nepal Asia $100 \quad$ Students $\quad \begin{aligned} & \text { Survey or } \\ & \text { questionnaire }\end{aligned}$ None $\quad$ Physiology

\begin{tabular}{|c|c|c|c|c|c|c|c|c|c|c|}
\hline 2001 & Bui-Mansfield & $\begin{array}{l}\text { United } \\
\text { States of } \\
\text { America }\end{array}$ & $\begin{array}{l}\text { America } \\
\text { (north) }\end{array}$ & 76 & $\begin{array}{l}\text { Students } \\
\text { and tutors }\end{array}$ & $\begin{array}{l}\text { Descriptive } \\
\text { experience }\end{array}$ & None & Radiology & $\begin{array}{l}\text { Not } \\
\text { specified }\end{array}$ & - \\
\hline 2001 & Dyke & Australia & Oceania & 136 & Students & $\begin{array}{l}\text { Comparative } \\
\text { and } \\
\text { randomized } \\
\text { study }\end{array}$ & $\begin{array}{l}\text { Traditional } \\
\text { or lecture }\end{array}$ & Epidemiology & Performance & $\begin{array}{l}\text { Stude } \\
\text { satisf }\end{array}$ \\
\hline
\end{tabular}

\begin{tabular}{|c|c|c|c|c|c|c|c|c|c|c|}
\hline 2001 & Brewer & $\begin{array}{l}\text { United } \\
\text { States of } \\
\text { America }\end{array}$ & $\begin{array}{l}\text { America } \\
\text { (north) }\end{array}$ & - & Students & $\begin{array}{l}\text { Descriptive } \\
\text { experience }\end{array}$ & $\begin{array}{l}\text { Traditional } \\
\text { or lecture }\end{array}$ & Endocrinology & Performance & - \\
\hline 2001 & Walters & $\begin{array}{l}\text { United } \\
\text { States of } \\
\text { America }\end{array}$ & $\begin{array}{l}\text { America } \\
\text { (north) }\end{array}$ & - & Students & $\begin{array}{l}\text { Survey or } \\
\text { questionnaire }\end{array}$ & None & Endocrinology & $\begin{array}{l}\text { Student } \\
\text { satisfaction }\end{array}$ & - \\
\hline 2001 & Leung & China & Asia & 320 & Students & $\begin{array}{l}\text { Survey or } \\
\text { questionnaire }\end{array}$ & None & Public Health & $\begin{array}{l}\text { Student } \\
\text { satisfaction }\end{array}$ & - \\
\hline
\end{tabular}

\begin{tabular}{|c|c|c|c|c|c|c|c|c|c|c|}
\hline 2001 & Curtis & $\begin{array}{l}\text { United } \\
\text { States of } \\
\text { America }\end{array}$ & $\begin{array}{l}\text { America } \\
\text { (north) }\end{array}$ & 639 & Students & $\begin{array}{l}\text { Comparative } \\
\text { non- } \\
\text { randomized } \\
\text { study }\end{array}$ & $\begin{array}{l}\text { Traditional } \\
\text { or lecture }\end{array}$ & Pediatric & $\begin{array}{l}\text { Knowledge } \\
\text { retention }\end{array}$ & $\begin{array}{l}\text { Stude } \\
\text { satisf }\end{array}$ \\
\hline
\end{tabular}

\begin{tabular}{|c|c|c|c|c|c|c|c|c|c|}
\hline 2001 & Seneviratne & Sri Lanka & Asia & 188 & Students & $\begin{array}{l}\text { Survey or } \\
\text { questionnaire }\end{array}$ & None & Not specified & Performance \\
\hline
\end{tabular}




\begin{tabular}{|c|c|c|c|c|c|c|c|c|c|}
\hline Year & Author & Country & Continent & $\begin{array}{l}\text { Sample } \\
\text { size }\end{array}$ & $\begin{array}{l}\text { Study } \\
\text { population }\end{array}$ & $\begin{array}{l}\text { Design } \\
\text { /Methodology }\end{array}$ & Comparator & Study subject & Outcome \\
\hline 2001 & Khoo & Singapore & Asia & - & $\begin{array}{l}\text { Students } \\
\text { and tutors }\end{array}$ & $\begin{array}{l}\text { Survey or } \\
\text { questionnaire }\end{array}$ & None & Not specified & $\begin{array}{l}\text { Student } \\
\text { satisfactio }\end{array}$ \\
\hline
\end{tabular}

2001 Villamor Philippines Asia $68 \quad$ Students $\begin{aligned} & \text { Survey or } \\ & \text { questionnaire }\end{aligned} \quad \begin{aligned} & \text { None } \\ & \begin{array}{l}\text { Biochemistry of } \\ \text { the endocrine } \\ \text { system }\end{array}\end{aligned}$

\begin{tabular}{|c|c|c|c|c|c|c|c|c|c|}
\hline 2002 & Trevena & Australia & Oceania & 130 & Students & $\begin{array}{l}\text { Survey or } \\
\text { questionnaire }\end{array}$ & None & Public Health & Performance \\
\hline 2002 & Alleyne & $\begin{array}{l}\text { Trinidad } \\
\text { and Tobago }\end{array}$ & $\begin{array}{l}\text { America } \\
\text { (south) }\end{array}$ & 129 & Students & $\begin{array}{l}\text { Comparative } \\
\text { non- } \\
\text { randomized } \\
\text { study }\end{array}$ & $\begin{array}{l}\text { Traditional } \\
\text { or lecture }\end{array}$ & $\begin{array}{l}\text { Medicine, } \\
\text { Surgery and } \\
\text { Obstetrics and } \\
\text { Gynecology }\end{array}$ & Performance \\
\hline
\end{tabular}

2002 Brynhildsen Sweden $\quad$ Europe $208 \quad \begin{aligned} & \text { Students } \\ & \text { and tutors }\end{aligned} \begin{aligned} & \begin{array}{l}\text { Survey or } \\ \text { questionnaire }\end{array} \\ & \text { None }\end{aligned} \quad$ Not specified

\begin{tabular}{|c|c|c|c|c|c|c|c|c|c|}
\hline 2002 & Astin & $\begin{array}{l}\text { United } \\
\text { Kingdom }\end{array}$ & Europe & - & Students & $\begin{array}{l}\text { Opinion, } \\
\text { editorial, } \\
\text { comment }\end{array}$ & None & $\begin{array}{l}\text { Medical } \\
\text { Statistics }\end{array}$ & Performance \\
\hline
\end{tabular}

2002 Whitfield $\quad \begin{array}{llllll}\text { United } & \begin{array}{l}\text { America } \\ \text { States of } \\ \text { America }\end{array} & 617 \quad \text { Students } & \begin{array}{l}\text { Comparative } \\ \text { non- } \\ \text { randomized } \\ \text { study }\end{array} & \begin{array}{l}\text { Traditional } \\ \text { or lecture }\end{array} & \text { Not specified }\end{array}$

\begin{tabular}{|c|c|c|c|c|c|c|c|c|c|c|}
\hline 2002 & Tousignant & Canada & $\begin{array}{l}\text { America } \\
\text { (north) }\end{array}$ & 70 & Students & $\begin{array}{l}\text { Survey or } \\
\text { questionnaire }\end{array}$ & None & Not specified & Other & \\
\hline
\end{tabular}




\begin{tabular}{|llllllllll}
\hline Year & Author & Country & Continent & $\begin{array}{l}\text { Sample } \\
\text { size }\end{array}$ & $\begin{array}{l}\text { Study } \\
\text { population }\end{array}$ & $\begin{array}{l}\text { Design } \\
\text { /Methodology }\end{array}$ & Comparator & Study subject & Outcome \\
\hline 2003 & Carrera & Argentina & $\begin{array}{l}\text { America } \\
\text { (south) }\end{array}$ & - & $\begin{array}{l}\text { Not } \\
\text { specified }\end{array}$ & $\begin{array}{l}\text { Descriptive } \\
\text { experience }\end{array}$ & None & Not specified & $\begin{array}{l}\text { Not } \\
\text { specified }\end{array}$ \\
\hline
\end{tabular}

\begin{tabular}{|c|c|c|c|c|c|c|c|c|c|}
\hline 2004 & Chang & China & Asia & 137 & Students & $\begin{array}{l}\text { Comparative } \\
\text { non- } \\
\text { randomized } \\
\text { study }\end{array}$ & $\begin{array}{l}\text { Traditional } \\
\text { or lecture }\end{array}$ & Anesthesia & $\begin{array}{l}\text { Student } \\
\text { satisfaction }\end{array}$ \\
\hline
\end{tabular}

\begin{tabular}{|c|c|c|c|c|c|c|c|c|c|}
\hline 2004 & McParland & $\begin{array}{l}\text { United } \\
\text { Kingdom }\end{array}$ & Europe & 379 & Students & $\begin{array}{l}\text { Comparative } \\
\text { non- } \\
\text { randomized } \\
\text { study }\end{array}$ & $\begin{array}{l}\text { Traditional } \\
\text { or lecture }\end{array}$ & Psychiatry & Performance \\
\hline
\end{tabular}

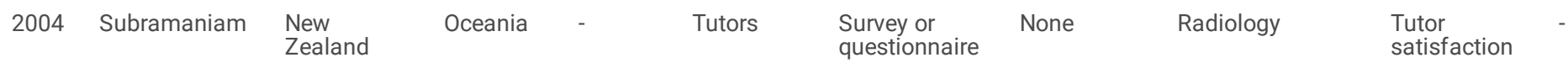

\begin{tabular}{|c|c|c|c|c|c|c|c|c|c|c|}
\hline 2004 & McLean & $\begin{array}{l}\text { South } \\
\text { Africa }\end{array}$ & Africa & 20 & Students & $\begin{array}{l}\text { Comparative } \\
\text { non- } \\
\text { randomized } \\
\text { study }\end{array}$ & $\begin{array}{l}\text { Traditional } \\
\text { or lecture }\end{array}$ & Not specified & $\begin{array}{l}\text { Student } \\
\text { satisfaction }\end{array}$ & - \\
\hline 2005 & Casey & $\begin{array}{l}\text { United } \\
\text { States of } \\
\text { America }\end{array}$ & $\begin{array}{l}\text { America } \\
\text { (north) }\end{array}$ & 162 & Students & $\begin{array}{l}\text { Comparative } \\
\text { non- } \\
\text { randomized } \\
\text { study }\end{array}$ & $\begin{array}{l}\text { Traditional } \\
\text { or lecture }\end{array}$ & $\begin{array}{l}\text { Obstetrics and } \\
\text { gynecology }\end{array}$ & Performance & $\begin{array}{l}\text { Stude } \\
\text { satisf: }\end{array}$ \\
\hline
\end{tabular}

\begin{tabular}{|c|c|c|c|c|c|c|c|c|c|}
\hline 2005 & Gurpinar & Turkey & Europe & 134 & Students & $\begin{array}{l}\text { Comparative } \\
\text { non- } \\
\text { randomized } \\
\text { study }\end{array}$ & $\begin{array}{l}\text { Traditional } \\
\text { or lecture }\end{array}$ & Public Health & Knowledge retention \\
\hline
\end{tabular}




\begin{tabular}{|llllllllll}
\hline Year & Author & Country & Continent & $\begin{array}{l}\text { Sample } \\
\text { size }\end{array}$ & $\begin{array}{l}\text { Study } \\
\text { population }\end{array}$ & $\begin{array}{l}\text { Design } \\
\text { /Methodology }\end{array}$ & Comparator & Study subject & Outcome \\
\hline 2005 & Tamblyn & Canada & $\begin{array}{l}\text { America } \\
\text { (north) }\end{array}$ & 751 & Students & $\begin{array}{l}\text { Comparative } \\
\text { non- } \\
\text { randomized } \\
\text { study }\end{array}$ & $\begin{array}{l}\text { Traditional } \\
\text { or lecture }\end{array}$ & Preventive Care & Performance \\
\hline
\end{tabular}

2005 Abu-Hijleh $\quad$ Bahrain $\quad$ Asia $131 \quad$ Students $\quad \begin{aligned} & \text { Survey or } \\ & \text { questionnaire }\end{aligned}$ None $\quad$ Surgery $\quad \begin{array}{lll}\text { Stude } \\ \text { satisf }\end{array}$

\begin{tabular}{|c|c|c|c|c|c|c|c|c|c|}
\hline 2005 & Kemahli & Turkey & Europe & - & $\begin{array}{l}\text { Not } \\
\text { specified }\end{array}$ & $\begin{array}{l}\text { Opinion, } \\
\text { editorial, } \\
\text { comment }\end{array}$ & None & Hematology & $\begin{array}{l}\text { Not } \\
\text { specified }\end{array}$ \\
\hline
\end{tabular}

\begin{tabular}{|c|c|c|c|c|c|c|c|c|c|}
\hline 2005 & $\begin{array}{l}\text { Salinas } \\
\text { Sánchez }\end{array}$ & Spain & Europe & - & $\begin{array}{l}\text { Not } \\
\text { specified }\end{array}$ & $\begin{array}{l}\text { Opinion, } \\
\text { editorial, } \\
\text { comment }\end{array}$ & None & Urology & $\begin{array}{l}\text { Not } \\
\text { specified }\end{array}$ \\
\hline
\end{tabular}

\begin{tabular}{|c|c|c|c|c|c|c|c|c|c|c|}
\hline 2005 & Distlehorst & $\begin{array}{l}\text { United } \\
\text { States of } \\
\text { America }\end{array}$ & $\begin{array}{l}\text { America } \\
\text { (north) }\end{array}$ & 648 & Students & $\begin{array}{l}\text { Comparative } \\
\text { non- } \\
\text { randomized } \\
\text { study }\end{array}$ & $\begin{array}{l}\text { Traditional } \\
\text { or lecture }\end{array}$ & $\begin{array}{l}\text { The global } \\
\text { curriculum }\end{array}$ & Performance & $\begin{array}{l}\text { Know } \\
\text { retent }\end{array}$ \\
\hline
\end{tabular}

\begin{tabular}{|c|c|c|c|c|c|c|c|c|c|}
\hline 20 & Grkoviæ & Australia & Oceania & - & $\begin{array}{l}\text { Not } \\
\text { specified }\end{array}$ & $\begin{array}{l}\text { Opinion, } \\
\text { editorial, } \\
\text { comment }\end{array}$ & None & Not specified & $\begin{array}{l}\text { Not } \\
\text { specified }\end{array}$ \\
\hline
\end{tabular}

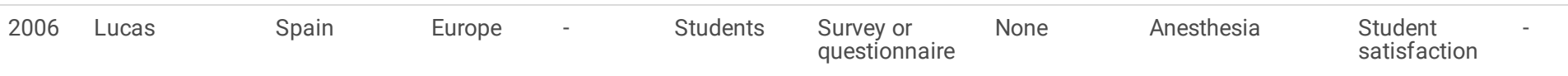




\begin{tabular}{|llllllllll}
\hline Year & Author & Country & Continent & $\begin{array}{l}\text { Sample } \\
\text { size }\end{array}$ & $\begin{array}{l}\text { Study } \\
\text { population }\end{array}$ & $\begin{array}{l}\text { Design } \\
\text { /Methodology }\end{array}$ & Comparator & Study subject & Outcome \\
\hline 2006 & Burgun & France & Europe & 177 & Students & $\begin{array}{l}\text { Survey or } \\
\text { questionnaire }\end{array}$ & None & $\begin{array}{l}\text { Medical } \\
\text { informatics }\end{array}$ & $\begin{array}{l}\text { Student } \\
\text { satisfaction }\end{array}$ \\
\hline
\end{tabular}

\begin{tabular}{|c|c|c|c|c|c|c|c|c|c|}
\hline 2006 & Steadman & $\begin{array}{l}\text { United } \\
\text { States of } \\
\text { America }\end{array}$ & $\begin{array}{l}\text { America } \\
\text { (north) }\end{array}$ & 31 & Students & $\begin{array}{l}\text { Comparative } \\
\text { and } \\
\text { randomized } \\
\text { study }\end{array}$ & Simulation & $\begin{array}{l}\text { Critical care } \\
\text { skills }\end{array}$ & Performance \\
\hline
\end{tabular}

\begin{tabular}{|c|c|c|c|c|c|c|c|c|c|}
\hline 2006 & Hoffman & $\begin{array}{l}\text { United } \\
\text { States of } \\
\text { America }\end{array}$ & $\begin{array}{l}\text { America } \\
\text { (north) }\end{array}$ & - & Students & $\begin{array}{l}\text { Comparative } \\
\text { non- } \\
\text { randomized } \\
\text { study }\end{array}$ & $\begin{array}{l}\text { Traditional } \\
\text { or lecture }\end{array}$ & $\begin{array}{l}\text { The global } \\
\text { curriculum }\end{array}$ & Performance \\
\hline
\end{tabular}

\begin{tabular}{|c|c|c|c|c|c|c|c|c|c|}
\hline 2008 & Norman & Canada & $\begin{array}{l}\text { America } \\
\text { (north) }\end{array}$ & 1166 & Students & $\begin{array}{l}\text { Comparative } \\
\text { non- } \\
\text { randomized } \\
\text { study }\end{array}$ & $\begin{array}{l}\text { Traditional } \\
\text { or lecture }\end{array}$ & Not specified & Performance \\
\hline
\end{tabular}

\begin{tabular}{|c|c|c|c|c|c|c|c|c|c|c|}
\hline 2008 & $\begin{array}{l}\text { Cohen- } \\
\text { Schotanus }\end{array}$ & Netherlands & Europe & 344 & Students & $\begin{array}{l}\text { Comparative } \\
\text { and } \\
\text { randomized } \\
\text { study }\end{array}$ & $\begin{array}{l}\text { Traditional } \\
\text { or lecture }\end{array}$ & Not specified & Performance & Other \\
\hline
\end{tabular}

2009 Wenk Germany Europe $33 \quad$ Students $\begin{aligned} & \text { Comparative Simulation Anesthesia } \\ & \text { and } \\ & \text { randomized } \\ & \text { study }\end{aligned} \quad$ Performance -

\begin{tabular}{|c|c|c|c|c|c|c|c|c|c|c|}
\hline 2009 & Kong & China & Asia & 90 & Students & $\begin{array}{l}\text { Comparative } \\
\text { and } \\
\text { randomized } \\
\text { study }\end{array}$ & $\begin{array}{l}\text { Traditional } \\
\text { or lecture }\end{array}$ & Ophthalmology & Performance & - \\
\hline
\end{tabular}




\begin{tabular}{|c|c|c|c|c|c|c|c|c|c|c|}
\hline Year & Author & Country & Continent & $\begin{array}{l}\text { Sample } \\
\text { size }\end{array}$ & $\begin{array}{l}\text { Study } \\
\text { population }\end{array}$ & $\begin{array}{l}\text { Design } \\
\text { /Methodology }\end{array}$ & Comparator & Study subject & Outcome & Outco \\
\hline 2009 & Collard & Belgium & Europe & 104 & Students & $\begin{array}{l}\text { Descriptive } \\
\text { experience }\end{array}$ & None & Endocrinology & $\begin{array}{l}\text { Knowledge } \\
\text { retention }\end{array}$ & Reasc \\
\hline
\end{tabular}

2009 Johnston China Asia $129 \quad$ Students $\begin{aligned} & \begin{array}{l}\text { Comparative } \\ \text { and } \\ \text { randomized } \\ \text { study }\end{array} \\ & \text { or lecture }\end{aligned}$

\begin{tabular}{|c|c|c|c|c|c|}
\hline Macallan & $\begin{array}{l}\text { United } \\
\text { Kingdom }\end{array}$ & Europe & $\begin{array}{l}\text { Students } \\
\text { and tutors }\end{array}$ & $\begin{array}{l}\text { Descriptive } \\
\text { experience }\end{array}$ & Not specified \\
\hline
\end{tabular}

\begin{tabular}{|c|c|c|c|c|c|c|c|c|c|}
\hline 2009 & Gurpinar & Turkey & Europe & 323 & $\begin{array}{l}\text { Students } \\
\text { and tutors }\end{array}$ & $\begin{array}{l}\text { Survey or } \\
\text { questionnaire }\end{array}$ & None & Not specified & $\begin{array}{l}\text { Student } \\
\text { satisfaction }\end{array}$ \\
\hline
\end{tabular}

2009 Tsou $\quad$ China $\quad$ Asia $71 \quad$ Students $\begin{aligned} & \text { Descriptive } \\ & \text { experience }\end{aligned} \quad$ None $\quad$ Not specified $\quad$ Performance $\quad \begin{aligned} & \text { Know } \\ & \text { retent }\end{aligned}$




\begin{tabular}{|llllllllll}
\hline Year & Author & Country & Continent & $\begin{array}{l}\text { Sample } \\
\text { size }\end{array}$ & $\begin{array}{l}\text { Study } \\
\text { population }\end{array}$ & $\begin{array}{l}\text { Design } \\
\text { /Methodology }\end{array}$ & Comparator & Study subject & Outcome \\
\hline 2009 & Lin & China & Asia & - & $\begin{array}{l}\text { Students } \\
\text { and tutors }\end{array}$ & $\begin{array}{l}\text { Descriptive } \\
\text { experience }\end{array}$ & None & Not specified & $\begin{array}{l}\text { Not } \\
\text { specified }\end{array}$ \\
\hline
\end{tabular}

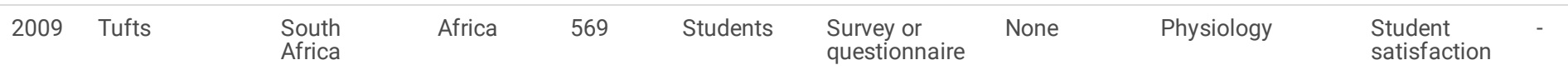

\begin{tabular}{|c|c|c|c|c|c|c|c|c|c|}
\hline 2010 & Suleman & $\begin{array}{l}\text { Saudi } \\
\text { Arabia }\end{array}$ & Asia & 54 & Students & $\begin{array}{l}\text { Comparative } \\
\text { non- } \\
\text { randomized } \\
\text { study }\end{array}$ & $\begin{array}{l}\text { Traditional } \\
\text { or lecture }\end{array}$ & Not specified & $\begin{array}{l}\text { Student } \\
\text { satisfaction }\end{array}$ \\
\hline
\end{tabular}

\begin{tabular}{|c|c|c|c|c|c|c|c|c|c|c|}
\hline 2010 & Wang & China & Asia & 173 & Students & $\begin{array}{l}\text { Comparative } \\
\text { non- } \\
\text { randomized } \\
\text { study }\end{array}$ & $\begin{array}{l}\text { Traditional } \\
\text { or lecture }\end{array}$ & Anatomy & Performance & $\begin{array}{l}\text { Stude } \\
\text { satisf: }\end{array}$ \\
\hline
\end{tabular}

2011 Abou-Elhamd Egypt Asia - $\quad \begin{aligned} & \text { Not } \\ & \text { specified }\end{aligned} \begin{aligned} & \text { Descriptive } \\ & \text { experience }\end{aligned}$ None Otolaryngology Knowledge retention

\begin{tabular}{|c|c|c|c|c|c|c|c|c|c|c|}
\hline 2011 & Urrutia & Mexico & $\begin{array}{l}\text { America } \\
\text { (south) }\end{array}$ & 340 & Students & $\begin{array}{l}\text { Comparative } \\
\text { non- } \\
\text { randomized } \\
\text { study }\end{array}$ & $\begin{array}{l}\text { Traditional } \\
\text { or lecture }\end{array}$ & Not specified & $\begin{array}{l}\text { Knowledge } \\
\text { retention }\end{array}$ & Other \\
\hline
\end{tabular}




\begin{tabular}{|c|c|c|c|c|c|c|c|c|c|c|}
\hline Year & Author & Country & Continent & $\begin{array}{l}\text { Sample } \\
\text { size }\end{array}$ & $\begin{array}{l}\text { Study } \\
\text { population }\end{array}$ & $\begin{array}{l}\text { Design } \\
\text { /Methodology }\end{array}$ & Comparator & Study subject & Outcome & Outco \\
\hline 2012 & Nouns & Germany & Europe & 240 & Students & $\begin{array}{l}\text { Comparative } \\
\text { and } \\
\text { randomized } \\
\text { study }\end{array}$ & $\begin{array}{l}\text { Traditional } \\
\text { or lecture }\end{array}$ & $\begin{array}{l}\text { Basic medical } \\
\text { sciences }\end{array}$ & Knowledge rete & ntion \\
\hline 2012 & Tian & China & Asia & 107 & Students & $\begin{array}{l}\text { Comparative } \\
\text { and } \\
\text { randomized } \\
\text { study }\end{array}$ & $\begin{array}{l}\text { Traditional } \\
\text { or lecture }\end{array}$ & $\begin{array}{l}\text { Evidence-based } \\
\text { medicine }\end{array}$ & Performance & $\begin{array}{l}\text { Stude } \\
\text { satisf: }\end{array}$ \\
\hline 2012 & Elzubeir & $\begin{array}{l}\text { Saudi } \\
\text { Arabia }\end{array}$ & Asia & 20 & $\begin{array}{l}\text { Students } \\
\text { and tutors }\end{array}$ & $\begin{array}{l}\text { Survey or } \\
\text { questionnaire }\end{array}$ & None & Renal system & $\begin{array}{l}\text { Student } \\
\text { satisfaction }\end{array}$ & - \\
\hline 2012 & Saloojee & $\begin{array}{l}\text { South } \\
\text { Africa }\end{array}$ & Africa & 1707 & Students & $\begin{array}{l}\text { Comparative } \\
\text { non- } \\
\text { randomized } \\
\text { study }\end{array}$ & $\begin{array}{l}\text { Traditional } \\
\text { or lecture }\end{array}$ & Psychiatry & Performance & - \\
\hline 2012 & Hoover & $\begin{array}{l}\text { United } \\
\text { States of } \\
\text { America }\end{array}$ & $\begin{array}{l}\text { America } \\
\text { (north) }\end{array}$ & 16 & Students & $\begin{array}{l}\text { Descriptive } \\
\text { experience }\end{array}$ & None & Public Health & Performance & - \\
\hline 2013 & $\mathrm{Li}$ & China & Asia & 120 & Students & $\begin{array}{l}\text { Comparative } \\
\text { and } \\
\text { randomized } \\
\text { study }\end{array}$ & $\begin{array}{l}\text { Traditional } \\
\text { or lecture }\end{array}$ & Dermatology & Performance & $\begin{array}{l}\text { Stude } \\
\text { satisf: }\end{array}$ \\
\hline 2013 & Sulaiman & $\begin{array}{l}\text { United Arab } \\
\text { Emirates }\end{array}$ & Asia & 217 & $\begin{array}{l}\text { Students } \\
\text { and tutors }\end{array}$ & $\begin{array}{l}\text { Survey or } \\
\text { questionnaire }\end{array}$ & None & Family Medicine & $\begin{array}{l}\text { Student } \\
\text { satisfaction }\end{array}$ & - \\
\hline
\end{tabular}




\begin{tabular}{|llllllllll}
\hline Year & Author & Country & Continent & $\begin{array}{l}\text { Sample } \\
\text { size }\end{array}$ & $\begin{array}{l}\text { Study } \\
\text { population }\end{array}$ & $\begin{array}{l}\text { Design } \\
\text { /Methodology }\end{array}$ & Comparator & Study subject & Outcome \\
\hline 2013 & Albarrak & $\begin{array}{l}\text { Saudi } \\
\text { Arabia }\end{array}$ & Asia & 200 & Students & $\begin{array}{l}\text { Survey or } \\
\text { questionnaire }\end{array}$ & $\begin{array}{l}\text { Traditional } \\
\text { or lecture }\end{array}$ & Not specified & $\begin{array}{l}\text { Student } \\
\text { satisfaction }\end{array}$ \\
\hline
\end{tabular}

\begin{tabular}{|c|c|c|c|c|c|c|c|c|c|}
\hline 2014 & Ding & China & Asia & 2061 & Students & $\begin{array}{l}\text { Systematic } \\
\text { review and } \\
\text { meta-analysis }\end{array}$ & $\begin{array}{l}\text { Traditional } \\
\text { or lecture }\end{array}$ & $\begin{array}{l}\text { Preventive } \\
\text { Medicine }\end{array}$ & Performance \\
\hline
\end{tabular}

\begin{tabular}{|c|c|c|c|c|c|c|c|c|c|}
\hline 2014 & Navarro & Chile & $\begin{array}{l}\text { America } \\
\text { (south) }\end{array}$ & 14 & Tutors & $\begin{array}{l}\text { Survey or } \\
\text { questionnaire }\end{array}$ & None & Not specified & $\begin{array}{l}\text { Tutor } \\
\text { satisfaction }\end{array}$ \\
\hline
\end{tabular}

\begin{tabular}{|c|c|c|c|c|c|c|c|c|c|}
\hline 2014 & Meo & $\begin{array}{l}\text { Saudi } \\
\text { Arabia }\end{array}$ & Asia & 60 & Students & $\begin{array}{l}\text { Survey or } \\
\text { questionnaire }\end{array}$ & $\begin{array}{l}\text { Traditional } \\
\text { or lecture }\end{array}$ & Respiratory & $\begin{array}{l}\text { Knowledge } \\
\text { retention }\end{array}$ \\
\hline
\end{tabular}

\begin{tabular}{|c|c|c|c|c|c|c|c|c|c|c|}
\hline 2014 & Khoshnevisasl & Iran & Asia & 40 & Students & $\begin{array}{l}\text { Comparative } \\
\text { and } \\
\text { randomized } \\
\text { study }\end{array}$ & $\begin{array}{l}\text { Traditional } \\
\text { or lecture }\end{array}$ & Pediatric & Performance & $\begin{array}{l}\text { Stude } \\
\text { satisf: }\end{array}$ \\
\hline
\end{tabular}

\begin{tabular}{|c|c|c|c|c|c|c|c|c|c|}
\hline & Grisham & Vietnam & Asia & 61 & $\begin{array}{l}\text { Students } \\
\text { and tutors }\end{array}$ & \multicolumn{2}{|r|}{ None } & Public Health & $\begin{array}{l}\text { Student } \\
\text { satisfaction }\end{array}$ \\
\hline
\end{tabular}




\begin{tabular}{|llllllllll}
\hline Year & Author & Country & Continent & $\begin{array}{l}\text { Sample } \\
\text { size }\end{array}$ & $\begin{array}{l}\text { Study } \\
\text { population }\end{array}$ & $\begin{array}{l}\text { Design } \\
\text { /Methodology }\end{array}$ & Comparator & Study subject & Outcome \\
\hline 2015 & Aboonq & $\begin{array}{l}\text { Saudi } \\
\text { Arabia }\end{array}$ & Asia & 110 & Tutors & $\begin{array}{l}\text { Survey or } \\
\text { questionnaire }\end{array}$ & None & Not specified & Other \\
\hline
\end{tabular}

\begin{tabular}{|c|c|c|c|c|c|c|c|c|}
\hline 2015 & Al-Drees & $\begin{array}{l}\text { Saudi } \\
\text { Arabia }\end{array}$ & Asia & 510 & Students & $\begin{array}{l}\text { Survey or } \\
\text { questionnaire }\end{array}$ & None & Knowledge retention \\
\hline
\end{tabular}

\begin{tabular}{|c|c|c|c|c|c|c|c|c|c|}
\hline & Al-Shaikh & $\begin{array}{l}\text { Saudi } \\
\text { Arabia }\end{array}$ & Asia & 52 & Students & $\begin{array}{l}\text { Survey or } \\
\text { questionnaire }\end{array}$ & None & Not specified & $\begin{array}{l}\text { Knowledge } \\
\text { retention }\end{array}$ \\
\hline
\end{tabular}

\begin{tabular}{|c|c|c|c|c|c|c|c|c|c|}
\hline 2015 & Khan & $\begin{array}{l}\text { Saudi } \\
\text { Arabia }\end{array}$ & Asia & 92 & $\begin{array}{l}\text { Students } \\
\text { and tutors }\end{array}$ & $\begin{array}{l}\text { Survey or } \\
\text { questionnaire }\end{array}$ & None & Not specified & $\begin{array}{l}\text { Student } \\
\text { satisfaction }\end{array}$ \\
\hline
\end{tabular}

\begin{tabular}{|c|c|c|c|c|c|c|c|c|c|}
\hline 2015 & Hande & India & Asia & 464 & Students & $\begin{array}{l}\text { Survey or } \\
\text { questionnaire }\end{array}$ & None & Not specified & $\begin{array}{l}\text { Knowledge } \\
\text { retention }\end{array}$ \\
\hline
\end{tabular}

\begin{tabular}{|c|c|c|c|c|c|c|c|c|c|}
\hline 2015 & Nosair & $\begin{array}{l}\text { United Arab } \\
\text { Emirates }\end{array}$ & Asia & 250 & Students & $\begin{array}{l}\text { Survey or } \\
\text { questionnaire }\end{array}$ & None & Not specified & $\begin{array}{l}\text { Student } \\
\text { satisfaction }\end{array}$ \\
\hline 2015 & González & Spain & Europe & 204 & Students & $\begin{array}{l}\text { Survey or } \\
\text { questionnaire }\end{array}$ & $\begin{array}{l}\text { Traditional } \\
\text { or lecture }\end{array}$ & Not specified & Performance \\
\hline
\end{tabular}




\begin{tabular}{|llllllllll}
\hline Year & Author & Country & Continent & $\begin{array}{l}\text { Sample } \\
\text { size }\end{array}$ & $\begin{array}{l}\text { Study } \\
\text { population }\end{array}$ & $\begin{array}{l}\text { Design } \\
\text { /Methodology }\end{array}$ & Comparator & Study subject & Outcome \\
\hline 2015 & Amoako-Sakyi & Ghana & Africa & - & $\begin{array}{l}\text { Not } \\
\text { specified }\end{array}$ & $\begin{array}{l}\text { Descriptive } \\
\text { experience }\end{array}$ & None & $\begin{array}{l}\text { The global } \\
\text { curriculum }\end{array}$ & $\begin{array}{l}\text { Not } \\
\text { specified }\end{array}$ \\
\hline
\end{tabular}

\begin{tabular}{|c|c|c|c|c|c|c|c|c|c|}
\hline 2016 & Yanamadala & $\begin{array}{l}\text { United } \\
\text { States of } \\
\text { America }\end{array}$ & $\begin{array}{l}\text { America } \\
\text { (north) }\end{array}$ & 202 & Students & $\begin{array}{l}\text { Survey or } \\
\text { questionnaire }\end{array}$ & None & Geriatric & Performance \\
\hline
\end{tabular}

2016 Demirören $\quad$ Turkey $\quad$ Europe $561 \quad$ Students $\quad \begin{aligned} & \text { Descriptive } \\ & \text { experience }\end{aligned} \quad$ None $\quad$ Not specified $\quad$ Other

\begin{tabular}{|c|c|c|c|c|c|c|c|c|c|}
\hline 2016 & Chang & $\begin{array}{l}\text { United } \\
\text { States of } \\
\text { America }\end{array}$ & $\begin{array}{l}\text { America } \\
\text { (north) }\end{array}$ & . & $\begin{array}{l}\text { Students } \\
\text { and tutors }\end{array}$ & $\begin{array}{l}\text { Opinion, } \\
\text { editorial, } \\
\text { comment }\end{array}$ & None & Not specified & $\begin{array}{l}\text { Tutor } \\
\text { satisfaction }\end{array}$ \\
\hline
\end{tabular}

2017 Balendran India $\quad$ Asia $\quad 26 \quad$ Students $\begin{aligned} & \begin{array}{l}\text { Comparative } \\ \text { non- } \\ \text { randomized } \\ \text { study }\end{array} \\ & \text { or lecture }\end{aligned}$

\begin{tabular}{|c|c|c|c|c|c|c|c|c|c|c|}
\hline 2017 & Chang & Taiwan & Asia & 94 & Students & $\begin{array}{l}\text { Survey or } \\
\text { questionnaire }\end{array}$ & $\begin{array}{l}\text { Traditional } \\
\text { or lecture }\end{array}$ & $\begin{array}{l}\text { Obstetrics and } \\
\text { gynecology }\end{array}$ & Performance & - \\
\hline 2017 & Tshitenge & Botswana & Africa & 81 & Students & $\begin{array}{l}\text { Survey or } \\
\text { questionnaire }\end{array}$ & None & $\begin{array}{l}\text { Family Medicine, } \\
\text { Internal } \\
\text { Medicine, } \\
\text { Pediatrics and } \\
\text { Surgery }\end{array}$ & $\begin{array}{l}\text { Student } \\
\text { satisfaction }\end{array}$ & - \\
\hline 2017 & Alduraywish & $\begin{array}{l}\text { Saudi } \\
\text { Arabia }\end{array}$ & Asia & 170 & Students & $\begin{array}{l}\text { Survey or } \\
\text { questionnaire }\end{array}$ & None & Not specified & $\begin{array}{l}\text { Student } \\
\text { satisfaction }\end{array}$ & - \\
\hline
\end{tabular}

2017 Eltony $\quad$ Egypt $\quad$ Asia $71 \quad$ Students $\quad \begin{aligned} & \text { Descriptive } \\ & \text { experience }\end{aligned} \quad \begin{array}{ll}\text { None } & \begin{array}{l}\text { Patient safety } \\ \text { education } \\ \text { program }\end{array} \\ \text { retention } & \begin{array}{l}\text { Stude } \\ \text { satisf }\end{array}\end{array}$




\begin{tabular}{|c|c|c|c|c|c|c|c|c|c|c|}
\hline Year & Author & Country & Continent & $\begin{array}{l}\text { Sample } \\
\text { size }\end{array}$ & $\begin{array}{l}\text { Study } \\
\text { population }\end{array}$ & $\begin{array}{l}\text { Design } \\
\text { /Methodology }\end{array}$ & Comparator & Study subject & Outcome & Outco \\
\hline 2018 & Zhang & China & Asia & 1487 & Students & $\begin{array}{l}\text { Systematic } \\
\text { review and } \\
\text { meta-analysis }\end{array}$ & $\begin{array}{l}\text { Traditional } \\
\text { or lecture }\end{array}$ & Radiology & Performance & - \\
\hline
\end{tabular}

\begin{tabular}{|c|c|c|c|c|c|c|c|c|c|}
\hline 2018 & Hincapié & Mexico & $\begin{array}{l}\text { America } \\
\text { (south) }\end{array}$ & 100 & Students & $\begin{array}{l}\text { Comparative } \\
\text { non- } \\
\text { randomized } \\
\text { study }\end{array}$ & $\begin{array}{l}\text { Traditional } \\
\text { or lecture }\end{array}$ & Biochemistry & Performance \\
\hline
\end{tabular}

2018 Mughal Pakistan Asia $210 \quad$ Students $\begin{aligned} & \text { Descriptive } \\ & \text { experience }\end{aligned} \quad$ None Not specified

2018 Yadav Nepal Asia $113 \quad$ Students $\quad \begin{aligned} & \text { Survey or } \\ & \text { questionnaire }\end{aligned} \quad$ None $\quad$ Not specified $\quad \begin{aligned} & \text { Student } \\ & \text { satisfaction }\end{aligned}$

2019 Ma China Asia $1003 \quad$ Students $\begin{aligned} & \text { Systematic } \\ & \text { review and } \\ & \text { meta-analysis }\end{aligned}$ or lecture $\begin{aligned} & \text { Traditional Pediatric } \\ & \text { Performance - }\end{aligned}$

2019 Berger Germany Europe $112 \quad$ Students $\begin{aligned} & \text { Comparative } \begin{array}{l}\text { Traditional } \\ \text { and } \\ \text { randomized lecture } \\ \text { study }\end{array} \\ & \begin{array}{l}\text { Cardiopulmonary Performance - } \\ \text { resuscitation }\end{array}\end{aligned}$

\begin{tabular}{|c|c|c|c|c|c|c|c|c|c|c|}
\hline 2019 & Alquliti & $\begin{array}{l}\text { Saudi } \\
\text { Arabia }\end{array}$ & Asia & 101 & Students & $\begin{array}{l}\text { Comparative } \\
\text { non- } \\
\text { randomized } \\
\text { study }\end{array}$ & $\begin{array}{l}\text { Traditional } \\
\text { or lecture }\end{array}$ & Not specified & Performance & - \\
\hline 2019 & Yoo & $\begin{array}{l}\text { Korea, } \\
\text { South }\end{array}$ & Asia & 118 & $\begin{array}{l}\text { Students } \\
\text { and tutors }\end{array}$ & $\begin{array}{l}\text { Survey or } \\
\text { questionnaire }\end{array}$ & None & Not specified & $\begin{array}{l}\text { Student } \\
\text { satisfaction }\end{array}$ & $\begin{array}{l}\text { Tutor } \\
\text { satisf: }\end{array}$ \\
\hline
\end{tabular}




\begin{tabular}{|c|c|c|c|c|c|c|c|c|c|c|}
\hline Year & Author & Country & Continent & $\begin{array}{l}\text { Sample } \\
\text { size }\end{array}$ & $\begin{array}{l}\text { Study } \\
\text { population }\end{array}$ & $\begin{array}{l}\text { Design } \\
\text { /Methodology }\end{array}$ & Comparator & Study subject & Outcome & $\overline{\text { Outco }}$ \\
\hline 2019 & Asad & $\begin{array}{l}\text { Saudi } \\
\text { Arabia }\end{array}$ & Asia & 120 & Students & $\begin{array}{l}\text { Comparative } \\
\text { non- } \\
\text { randomized } \\
\text { study }\end{array}$ & $\begin{array}{l}\text { Traditional } \\
\text { or lecture }\end{array}$ & Not specified & $\begin{array}{l}\text { Student } \\
\text { satisfaction }\end{array}$ & - \\
\hline 2019 & $\mathrm{Hu}$ & China & Asia & 74 & Students & $\begin{array}{l}\text { Comparative } \\
\text { and } \\
\text { randomized } \\
\text { study }\end{array}$ & $\begin{array}{l}\text { Traditional } \\
\text { or lecture }\end{array}$ & Endocrinology & $\begin{array}{l}\text { Knowledge } \\
\text { retention }\end{array}$ & $\begin{array}{l}\text { Stude } \\
\text { satisf: }\end{array}$ \\
\hline
\end{tabular}

\begin{tabular}{|c|c|c|c|c|c|c|c|c|c|c|}
\hline 2019 & Thompson & Georgia & Europe & 213 & Students & $\begin{array}{l}\text { Comparative } \\
\text { non- } \\
\text { randomized } \\
\text { study }\end{array}$ & $\begin{array}{l}\text { Traditional } \\
\text { or lecture }\end{array}$ & $\begin{array}{l}\text { Anatomy } \\
\text { (Cadaveric } \\
\text { Dissection) }\end{array}$ & Performance & - \\
\hline
\end{tabular}

\begin{tabular}{|c|c|c|c|c|c|c|c|c|c|}
\hline 2019 & Aldayel & $\begin{array}{l}\text { Saudi } \\
\text { Arabia }\end{array}$ & Asia & 259 & Students & $\begin{array}{l}\text { Survey or } \\
\text { questionnaire }\end{array}$ & None & Not specified & $\begin{array}{l}\text { Student } \\
\text { satisfaction }\end{array}$ \\
\hline
\end{tabular}

2020 Mpalanyi Uganda Africa $18 \quad$ Students $\quad \begin{aligned} & \text { Survey or } \\ & \text { questionnaire }\end{aligned}$ None $\quad$ Radiology

\begin{tabular}{|c|c|c|c|c|c|c|c|c|c|c|}
\hline 2020 & $\mathrm{Li}$ & China & Asia & 122 & Students & $\begin{array}{l}\text { Comparative } \\
\text { and } \\
\text { randomized } \\
\text { study }\end{array}$ & $\begin{array}{l}\text { Traditional } \\
\text { or lecture }\end{array}$ & $\begin{array}{l}\text { Clinical } \\
\text { laboratory }\end{array}$ & Performance & $\begin{array}{l}\text { Stude } \\
\text { satisf: }\end{array}$ \\
\hline
\end{tabular}

2020 Zhao China Asia $354 \quad$ Students $\begin{aligned} & \begin{array}{l}\text { Comparative } \\ \text { and } \\ \text { randomized } \\ \text { study }\end{array} \\ & \text { or lecture }\end{aligned}$




\begin{tabular}{|c|c|c|c|c|c|c|c|c|c|c|}
\hline Year & Author & Country & Continent & $\begin{array}{l}\text { Sample } \\
\text { size }\end{array}$ & $\begin{array}{l}\text { Study } \\
\text { population }\end{array}$ & $\begin{array}{l}\text { Design } \\
\text { /Methodology }\end{array}$ & Comparator & Study subject & Outcome & Outco \\
\hline 2020 & Liu & China & Asia & 1817 & Students & $\begin{array}{l}\text { Systematic } \\
\text { review and } \\
\text { meta-analysis }\end{array}$ & $\begin{array}{l}\text { Traditional } \\
\text { or lecture }\end{array}$ & Variable & $\begin{array}{l}\text { Knowledge } \\
\text { retention }\end{array}$ & $\begin{array}{l}\text { Stude } \\
\text { satisf }\end{array}$ \\
\hline 2020 & Margolius & $\begin{array}{l}\text { United } \\
\text { States of } \\
\text { America }\end{array}$ & $\begin{array}{l}\text { America } \\
\text { (north) }\end{array}$ & 68 & Students & $\begin{array}{l}\text { Survey or } \\
\text { questionnaire }\end{array}$ & None & Not specified & Performance & - \\
\hline 2020 & Korkmaz & Turkey & Europe & 354 & Students & $\begin{array}{l}\text { Survey or } \\
\text { questionnaire }\end{array}$ & None & Not specified & $\begin{array}{l}\text { Student } \\
\text { satisfaction }\end{array}$ & - \\
\hline
\end{tabular}

\section{Figures}

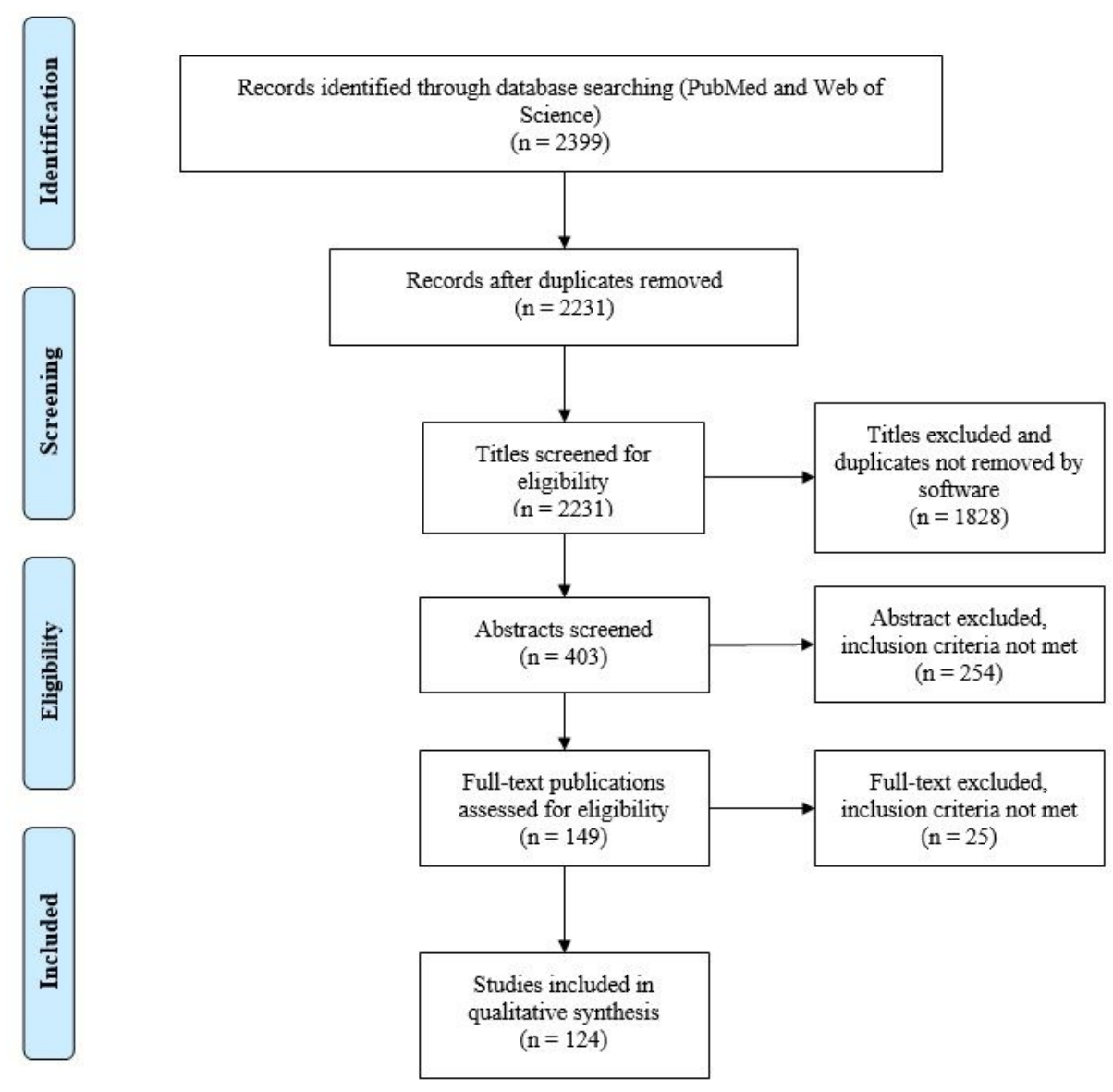

Figure 1

Study flow PRISMA diagram. Details the review process through the different stages of the review; includes the number of records identified, included and excluded 


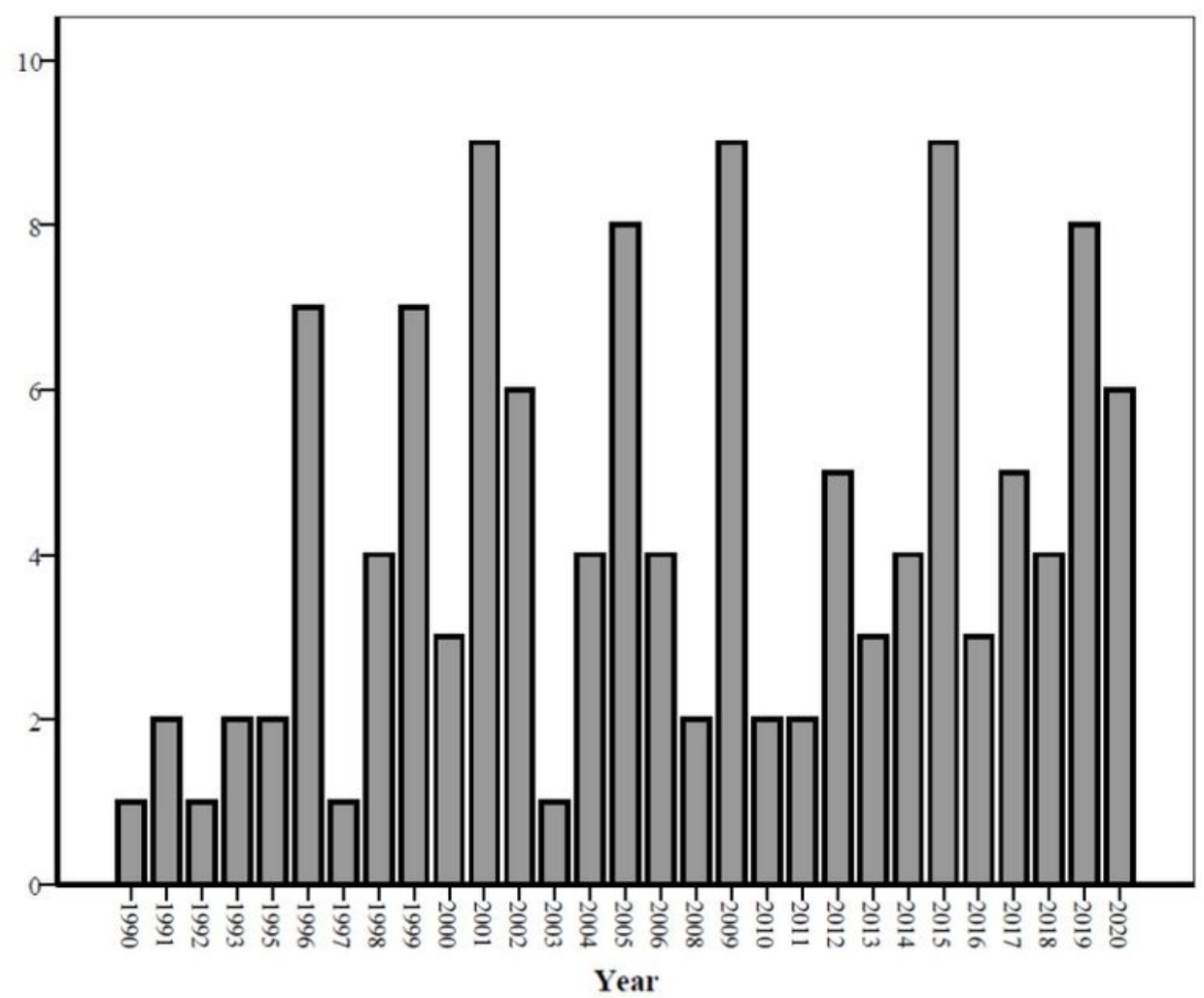

Figure 2

Number of articles by year of publication 